NBER WORKING PAPER SERIES

WASTE OF EFFORT? INTERNATIONAL ENVIRONMENTAL AGREEMENTS

Derek Kellenberg

Arik Levinson

Working Paper 19533

http://www.nber.org/papers/w19533

\author{
NATIONAL BUREAU OF ECONOMIC RESEARCH \\ 1050 Massachusetts Avenue \\ Cambridge, MA 02138 \\ October 2013
}

The authors are grateful to Jen Baggs for sharing her compilation of Basel data, and to Matilde Bombardini and numerous participants at the Swiss Federal Institute of Technology, the University of Bologna, the 2011 University of British Columbia Workshop on Environmental Economics and Climate Change, and the Stanford Institute for Theoretical Economics 2013 Summer Workshop for constructive suggestions. The views expressed herein are those of the authors and do not necessarily reflect the views of the National Bureau of Economic Research.

NBER working papers are circulated for discussion and comment purposes. They have not been peerreviewed or been subject to the review by the NBER Board of Directors that accompanies official NBER publications.

(C) 2013 by Derek Kellenberg and Arik Levinson. All rights reserved. Short sections of text, not to exceed two paragraphs, may be quoted without explicit permission provided that full credit, including (C) notice, is given to the source. 
Waste of Effort? International Environmental Agreements

Derek Kellenberg and Arik Levinson

NBER Working Paper No. 19533

October 2013

JEL No. F13,F18,Q53,Q56

\begin{abstract}
Many of the world's environmental problems cross international borders, and to address those problems approximately 1,000 different International Environmental Agreements (IEAs) are in operation today. Most evidence, however suggests that those IEAs are ineffectual, merely ratifying business-as-usual outcomes and doing little to improve the environment. But much of that empirical analysis faces two obstacles: (1) limited data from before the IEAs were enacted and thus an inability to make before-andafter comparisons; and (2) difficulty estimating the counterfactual outcomes - what would have happened absent the agreements. In this paper we test the effectiveness of one particular IEA - the Basel Convention on the Control of Transboundary Movements of Hazardous Wastes and their Disposal. In this special case we have data on international waste shipments from both before and after countries ratify the agreement, along with a unique approach to identifying the treaty's effect using annual bilateral waste shipments among countries before and after one of the trading partners signs the agreement. Despite the strengths of this approach, we find almost no evidence that the Convention has resulted in less waste being shipped among countries.
\end{abstract}

\author{
Derek Kellenberg \\ Economics Department \\ University of Montana \\ 32 Campus Dr. \#5472 \\ Missoula, MT 59812-5472 \\ derek.kellenberg@mso.umt.edu \\ Arik Levinson \\ Department of Economics ICC 571 \\ Georgetown University \\ 3700 O St., NW \\ Washington, DC 20057 \\ and NBER \\ aml6@georgetown.edu
}




\section{Waste of Effort? International Environmental Agreements}

\section{Introduction}

Many of the worlds' pressing environmental problems are international, from endangered species, to the hole in the ozone layer, to greenhouse gas emissions and climate change. Attempts to address these problems have involved international cooperation - in some cases on an unprecedented scale. However, economic research has so far yielded little evidence that international environmental agreements (IEAs) can meet these global challenges. Economic theories demonstrate that due to free ridership problems IEAs can achieve little more than what individual countries would volunteer without the agreements, and far less than what would be globally optimal. Most empirical work supports the theories, finding that IEAs result in no improvements beyond what would have occurred in their absence.

Are IEAs effective? The empirical work to date has faced two obstacles to answering that question. First, IEAs typically require member countries, as a first step towards compliance, to begin reporting data on their contributions to the relevant environmental problem. The Montreal Protocol required countries to report their production and consumption of ozone-depleting substances, but only signatories report, and only after they join the treaty. It is hard to know what countries were doing before they joined, or to compare signatories to non-signatories. ${ }^{1}$ More importantly and more generally, researchers have a hard time differentiating countries' actions after signing IEAs from what they would have done absent the IEAs. If an environmental problem worsens after member countries enact an IEA, but worsens less than if the countries had not acted, the agreement might be falsely deemed a failure despite its success in slowing

\footnotetext{
${ }^{1}$ See, for example, Murdock, et al. (1997a and 1997b), Cole et al. (1997), Auffhammer et al. (2005).
} 
pollution growth. Conversely, if countries expecting emissions reductions are more likely to sign an IEA, the agreement might be falsely deemed successful despite merely ratifying business-asusual practices.

In this paper we examine one particular IEA that enables us to address both problems: the Basel Convention on the Control of Transboundary Movements of Hazardous Waste and their Disposal. The Convention was adopted in the context of growing international shipments of hazardous waste - so-called "toxic trade" - from industrialized countries to parts of the world where disposal was less expensive and presumably less safe. The Convention's central goal is "restriction of transboundary movements of hazardous waste except where it is perceived to be in accordance with the principles of environmentally sound management." ${ }^{2}$ Starting in the early 1990s, the Basel Convention required member countries to publicly report details about their exports and imports of hazardous and other waste. Then in 1995, the Convention's Ban Amendment prohibited all exports of hazardous waste from countries listed in Annex VII (all OECD and European Union countries plus Liechtenstein) to all other countries not listed in Annex VII (henceforth A7 and non-A7 countries).

At the simplest level, international hazardous waste trade would not appear to fit the standard characteristics of an environmental problem requiring international cooperation. If waste is improperly handled, that creates local pollution, not cross-border externalities or openaccess "tragedy of the commons" overuse problems. If every country regulates hazardous waste disposal appropriately within its borders, international waste trade is efficient and welfareimproving just like trade in any good or service. All the usual comparative advantage arguments for free trade apply. But as has long been recognized, if some countries cannot appropriately regulate natural resources or pollution emissions within their borders, trade restrictions may be a

\footnotetext{
${ }^{2}$ http://www.basel.int/TheConvention/Overview/tabid/1271/Default.aspx, accessed July 17, 2013.
} 
second-best policy. ${ }^{3}$ Throughout this paper we assume that to be the fundamental motivation for the Basel Convention and Ban - the concern that some countries' institutions are incapable of providing their citizens with their desired level of "environmentally sound management" of hazardous waste, and that those countries are better off limiting their imports through international treaties.

To assess whether the Basel Convention or the Ban succeeds in achieving that secondbest policy and alters waste shipments beyond what would have occurred anyway, we use a variant of the gravity model of international trade, 60 six-digit Harmonized System (HS) tariff codes describing bilateral shipments of various types of waste among 124 countries over 17 years, and data on if and when those countries ratified the Basel Convention or its Ban Amendment. We pose two basic questions.

First, we ask whether the Basel Convention, independent of the Ban Amendment, did anything to reduce waste flows among ratifying countries. Descriptive statistics suggest that countries ratifying the Convention were those countries with slower-than-average growth in hazardous waste trade, and that the Convention did nothing to alter that pattern. Controlling for other country characteristics, those that signed the Convention did export less hazardous waste, but our inference is that they would have done so anyway.

Second, we ask whether the subsequent Ban Amendment had any effect. This is where our unique identification strategy has power, because the Ban Amendment restricts one particular type of waste trade - shipments from A7 to non-A7 countries. While controlling for other country characteristics, we interact controls for Ban ratification with controls for A7-tonon-A7 shipments. We find that although A7 countries signing the Ban do appear to export less waste to non-A7 countries, that effect disappears once we include country-year fixed effects or

\footnotetext{
${ }^{3}$ See Brander and Taylor (1997), Copeland (1991), and Chichilnisky (1994).
} 
country-pair fixed effects, suggesting that signing the Ban, like the Convention itself, merely ratified existing trends in waste trade for A7 ratifying countries. One possible explanation for the treaty's lack of apparent effect on A7 exports is trade diversion. Countries banned from shipping waste to non-A7 importers may transship that waste via non-signatories. We explore this possibility but find no aggregate evidence that trade diversion has circumvented the treaty's intents.

Although we had expected that the empirical advantages of our approach might help us to overcome the obstacles faced by earlier research and yield results consistent with an IEA improving environmental outcomes, we find no evidence that A7 countries that signed the Ban slowed their exports to non-A7 countries as the agreement requires. We do find limited evidence that non-A7 countries that signed the Ban have slowed their imports of the most toxic waste from A7 countries, a result consistent with Copeland's (1991) finding that trade restrictions may be welfare improving for small countries that are unable to enforce domestic environmental regulations. After controlling for a number of empirical issues, including endogeneity and unobserved country characteristics, this is the only effect we find in terms of the Ban reducing bilateral waste trade.

Before describing our model and data in detail, we begin with some background on IEAs in general, and the details of international hazardous waste trade and the Basel Convention.

\section{Background}

IEAs have been proliferating. From 1951 to 1980, 216 new multilateral IEAs or protocols were enacted worldwide; in the following 30 years, through 2010, 398 new multilateral IEAs and 
protocols were enacted (Mitchell, 2002-2011). Today, more than 1,000 multilateral IEAs are in operation. ${ }^{4}$

\section{The Economics of IEAs}

According to most theoretical economic models, all these new IEAs will have been largely ineffective. Typical theoretical results show that IEAs can do little to improve the environment beyond non-cooperative outcomes (Barrett, 1994 and 1997a; Carraro and Siniscalco, 1993). Due to the obvious free-rider problem, models demonstrate that equilibrium participation in IEAs will be small, or that larger coalitions can only be supported if the abatement targets are far less than the social optimum (Finus and Maus, 2008). Of course, game theoretic models do not necessarily predict behavior, and IEAs might be effective despite theories to the contrary.

The few empirical examinations of this issue have also failed to find significant effects of IEA participation on pollution. These have included studies of sulfur emissions and the Helsinki Protocol, ozone-depleting substances and the Montreal Protocol, and sulfur emissions again under the Oslo Protocol. ${ }^{5}$ The lone paper finding statistically significant consequences of an IEA is Bratberg, Tjøtta, and Øines (2005) who find that countries ratifying the Sofia Protocol reduced their nitrogen oxide emissions relative to non-ratifying countries. But even this result is consistent with Finus and Maus's (2008) theoretical finding that any IEA gains will be small and far from the social optimum.

Given the lack of theoretical and empirical evidence that voluntary IEAs can solve international environmental issues, their growing prevalence remains a puzzle. Rose and Spiegel (2009) provide evidence for one plausible explanation: that participation in noneconomic

\footnotetext{
${ }^{4}$ International Environmental Agreements Database Project website (iea.uoregon.edu).

${ }^{5}$ See Murdoch and Sandler (1997, 2007b), Ringquist and Kostadinova (2005), and Finus and Tjøtta (2003).
} 
international partnerships such as IEAs facilitates spillovers to other potentially more meaningful economic sectors, such as international lending. In other words, countries join IEAs and comply with their stipulations in order to gain the benefits of other international cooperation.

Whatever the reason for their prevalence, IEAs are the primary mechanism for efforts to solve global environmental problems. It is therefore critical that we try to understand whether IEAs can succeed. For that we turn to one particular IEA, the Basel Convention, with two distinct advantages. It governs international waste trade, about which we have data for countries before and after they join the agreement; and countries trade with multiple partners, providing numerous sources of identification that can potentially solve the problems associated with countries' endogenous decisions to join.

\section{The Basel Convention and Ban Amendment}

International hazardous waste trade has been growing exponentially. Between 1992 and 2008, the total physical volume of waste traded internationally grew 500 percent, from 45 to 221 million tons. For context, the total weight of all passenger automobiles shipped internationally in 2008 was 48 million tons - one-fifth the weight of the waste traded that year. To the extent that waste is exported to countries with safe and environmentally responsible recycling or disposal capacity, then waste trade may be seen as economically efficient in the same sense as goods trade. But if waste is exported to less developed countries with lax safety or environmental regulations, then waste trade may be creating substantial environmental problems in the importing countries. Indeed, Puckett and Smith (2002), Puckett (2005), and Pellow (2007) have all documented drastic environmental degradation occurring in Asia and North Africa where hazardous waste - especially used electronics - is being imported from developed countries. In 
that case, an IEA might help by enlisting the cooperation of exporters limiting their shipments to countries struggling to limit their imports.

The Basel Convention came into force in 1992, and aims to "protect human health and the environment against the adverse effects resulting from the generation, management, transboundary movements and disposal of hazardous and other wastes." It is the most comprehensive IEA governing hazardous and other wastes, and it had 175 participants by 2011. While the Convention has a number of goals and objectives for reducing the generation and management of waste, its primary policy tool is a ban on shipping waste across country borders. Article 4 of the convention stipulates, among other things, that: $(i)$ countries may ban hazardous waste imports; (ii) waste-exporting countries must honor bans by waste importers; (iii) importers must be alerted to shipments and must approve the shipments in writing; and (iv) ratified countries may not ship waste to or from countries that have not ratified the Convention. ${ }^{6}$

All else equal, points $(i)$ and $(i i)$ above should lead to a reduction in international waste trade if importing countries announce a ban and exporting countries enforce the prohibition on exports to those countries. However, the effects of points (iii) and (iv) are less clear. Although they were likely intended to increase transparency and to create an incentive for countries to join the convention, critics argued that these components of the Basel Convention did more to legitimize international waste trade than to reduce it. A non-ratified country that was previously unable to trade with a ratified member (point $i v$. above), could simply ratify their membership in the convention and then choose to accept properly announced waste shipments (point iii. above). In this case, once both countries have ratified the Basel Convention we could see an increase, rather than a decrease, in waste trade between them.

\footnotetext{
${ }^{6}$ See Article 4 of the Convention, Sections 1(a), 1(b), 1(c) and 2(f); and Article 5.
} 
To be clear, this may be more of a concern about empirical strategies than about real effects. Taking the Convention as given, if one member of a pair of trading countries signs, waste shipments to and from the non-signing member should drop. If the second country then signs, waste shipments can increase relative to when only one member had signed. In our analysis, we must be careful to distinguish two effects: the effect of the Convention and Ban on signatory countries relative to non-participants; and the overall effect of the Convention and Ban relative to a world without those IEAs.

In response to concerns about the Convention legitimizing toxic trade, in 1995 the Ban Amendment prohibited A7 countries from exporting hazardous and other waste to non-A7 countries, whether or not the importers are Basel signatories. The Ban first went into force for ratified countries in $1998 .^{7}$ If the Ban has been effective then we should expect a reduction of waste exports from ratifying A7 countries to non-A7 countries.

The Basel Convention and Ban Amendment are in some ways ideal circumstances in which to assess empirically the effect of IEAs. The stated environmental goals of the Convention (restricting the movements of waste products to countries ill equipped to safely handle them) are directly linked to patterns of international trade, about which there are abundant data. Moreover, those trade flows are measureable across time and countries. And finally, most countries trade waste with numerous other countries, providing multiple sources of identification. We can assess the effect of the Convention and Ban across countries in a given year, over time for a given country, across trading partners for a given country in a single year, and even within pairs of countries over time before and after they sign the IEAs.

\footnotetext{
${ }^{7}$ The Ban Amendment is not yet officially part of the Basel Convention as there is still legal uncertainty about how many countries must ratify the Ban for it to take effect. However, most countries that have ratified the Ban did so as part of their domestic law regarding waste exports.
} 
We combine information about countries' ratifications of the Convention and Ban with detailed bilateral international waste trade data based on the Harmonized Commodity Description and Coding System (HS), yielding a comprehensive panel dataset covering 124 countries over 21 years. Using variants of the standard gravity model of trade, we explicitly test the effectiveness of the Basel Convention and the Ban Amendment, while controlling for endogenous selection into the agreements by comparing the effects of countries over time and across pairs of countries. This allows us to test specifically whether the trade restrictions had any significant effects on international waste trade by participating members relative to what would have happened without the restrictions.

\section{International Waste Trade Data and Trends}

The Basel Convention requires members to report their hazardous waste imports and exports, but those data cannot be used to compare members to non-members, or to study members before and after signing the Convention. As a consequence, we use a close proxy for the waste trade governed by Basel: the United Nations Comtrade database and 60 six-digit Harmonized System (HS6) tariff codes for which the product description lists "waste", "scrap", "slag", "residue", or "ash" as the primary descriptor of the product. ${ }^{8}$ Appendix Table A1 lists each of the 60 waste categories, along with their HS6 codes. Data were collected for all bilateral trading pairs of 124 countries with at least some positive quantity of trade from 1988 to 2008.

Our main unit of observation is the aggregate annual tonnage of waste traded between countries, summed across the 60 waste classifications in Table A1. Each country pair potentially appears twice per year: once for each direction of waste flows. In total, there are 640,584 possible

\footnotetext{
${ }^{8}$ The UN Comtrade database can be found at http://comtrade.un.org/.
} 
observations. ${ }^{9}$ After omitting country pairs with zero waste trade, or for which GDP data were unavailable, we are left with 46,149 observations.

The Convention's definition of "hazardous" relies on the waste's characteristics (ecotoxic, corrosive, flammable, poisonous, infectious, oxidizing, toxic, etc.), while the HS6 data we used to assemble Table A1 are based on product descriptions. ${ }^{10}$ Each of the 60 categories in Table A1 can have both hazardous and non-hazardous components. As an example, consider HS6 code 720449 for ferrous waste or scrap metal - one of the largest components of waste trade by weight. A crushed car would be in this HS code, and so we classify it as waste trade, but whether the Convention would classify that car as hazardous depends on whether its oil, transmission fluid, and antifreeze had been removed before it was crushed. Even product categories whose descriptions may appear safe can be hazardous under the convention. Scrap glass (HS6 711210) is hazardous if it is from computer monitors containing lead; sawdust (400400) is hazardous if it has been used to absorb industrial solvents. As a consequence, our Comtrade waste data do not perfectly match the Convention's definition of hazardous waste, but they do allow us to compare Convention and Ban signatories to non-signatories before and after the agreements were in force.

As a check on this proxy, we also create a second definition of hazardous trade using 20 of our original 60 waste categories where the description in the Basel Conventions' Annex VIII list of hazardous waste products match closely to the product descriptions in the HS code. These are listed in Appendix Table A2. Each of these 20 product categories are certain to contain

\footnotetext{
${ }^{9}$ Two directions $\times 124$ exporters $\times 123$ importers $\times 21$ years.

${ }^{10}$ Annex II and Annex VIII of the Basel Convention describe waste streams and categories of products that are considered hazardous, while Annex IV describes wastes considered non-hazardous.
} 
products that are completely, or nearly completely, composed of wastes considered hazardous under the Basel Convention. ${ }^{11}$

Finally, we can compare our Comtrade proxy to the actual voluntarily reported hazardous waste trade data collected under the auspices of the Basel Convention, for those countries that have ratified the Convention and for the years following their ratification. Table 1 presents these correlations, including official Basel data for 1994-2003. The two types of waste shipments listed in Tables A1 and A2 are positively correlated but not completely collinear $(\rho=0.403)$. And both Comtrade proxies are correlated with the official Basel Convention data $(\rho=0.507$ and $0.367) .^{12}$

The complex annual data on waste volumes shipped in each direction between each pair of countries, differentiated by A7 status, provides a number of different ways to identify the treaty's effects. Figure 1 diagrams the possibilities. There are four types of exporters (A7 and non-A7 signatories and non-signatories) and four types of importers, yielding sixteen different types of annual waste shipments. The Convention's objective is to restrict international shipments in general, though it was motivated by the growth in shipments to developing (non-A7) countries. Accordingly, if the Convention is successful, we should see a decline in exports by signatories, especially to non-A7 countries. This could be identified from a number of differences in the data: smaller exports from $\mathrm{A}$ and $\mathrm{C}$ than from $\mathrm{B}$ and $\mathrm{D}$; smaller exports from $\mathrm{C}$ to $\mathrm{E}$ and $\mathrm{F}$ than from $\mathrm{D}$ to $\mathrm{E}$ and $\mathrm{F}$; or smaller shipments among signatories $\mathrm{A}, \mathrm{E}, \mathrm{C}$, and $\mathrm{G}$ than among non-signatories. Each of these differences can be examined across countries, or within countries or country-pairs over time, when one country ratifies the Convention or the Ban. I.e.

\footnotetext{
${ }^{11}$ These are not official concordances, but are concordances made by us based on the commodity descriptions in both the HS6 code and the codes in Annex VIII of the Basel Convention.

${ }^{12}$ Under the Convention, both exporters and importers report waste shipments, and so there are two separate measures. Here we report the import-based data, though correlations with the export-based data are similar.
} 
we should see shipments from an A7 to a non-A7 country decline, or at least increase less relative to other country pairs, when the A7 country signs the Ban.

Table 2 begins to describe these data. From 1988 to 2008, 2.2 billion tons of waste was shipped among countries. More than half of this waste was shipped among A7 countries (A7 to A7). Shipments from A7 to non-A7 countries make up the second largest component of waste trade. These developed-to-developing country shipments are the primary target of the Basel Convention and Ban. By weight, shipments from non-A7 countries, in columns (4) and (5) make up only a small part of international waste trade. Column (1) also shows that the average annual shipment among countries in our data was 47 thousand tons, and that the average annual shipment between pairs of A7 countries (96 thousand tons) was more than twice as large as the average annual shipment from A7 to non-A7 countries.

Table 3 examines the two key categories - A7 to A7 and A7 to non-A7 - broken down into groups according to whether the importer, the exporter, or both countries have ratified the Basel Convention or the Ban. ${ }^{13}$ The top panel focuses on the Convention. Relatively few countries trading waste were not signatories. Of the 13,561 A7-to-A7 shipments and the 10,083 A7-to-nonA7, most involve both countries having signed onto the Convention. This suggests it may be difficult to identify the effect of the Convention on waste trade.

The Ban, however, presents a sharper contrast in the bottom panel of Table 2. For one third of the annual country-pairs, neither country had signed the Ban. But in most of the comparisons, regardless of whether either party signed the Ban, it remains true that the average annual shipment among A7 countries remains much larger than the average from A7 to non-A7 countries. The notable exception is in row 7, when the waste importer has signed the Ban. Here

\footnotetext{
${ }^{13}$ Data for Basel Convention and Ban Amendment ratification dates comes from the "Status of Ratifications" tab on the Basel Convention website www.basel.int.
} 
waste shipments to non-A7 importers are larger, though not significantly so. In other words, precisely those shipments prohibited by the Ban are largest when the waste importer is a signatory.

There are two likely explanations for the odd difference of means in row 7 of Table 3 , each with its own implications for our attempt to estimate the efficacy of the Ban. First, non-A7 countries may have limited enforcement capacity, and the Ban may therefore be ineffectual unless the A7 exporter signs on. This first explanation simply suggests that we need to examine separately the effects of the importer and exporter's signatory status. Given the large number of countries involved and our 21-year panel, parsing the analysis in this way poses no problem. However, other counterintuitive differences in Table 3 suggest there is more going on here than simple differences of means can explain. For example, when the exporter signs the Ban, waste shipments to non-A7 countries (row 6, 27 thousand tons) are smaller than when neither country signs (row 5, 34 thousand tons), which makes sense, but lower than when both countries sign (row 8, 57 thousand tons). In other words, when the importer signs the Ban waste imports are larger, even when we limit the comparison to country-pairs where the exporter has signed.

This raises a second possible explanation for the odd result in row (7), that treaty signatory status may be endogenous. Non-A7 importers that find themselves receiving large quantities of hazardous waste may be more likely to sign the Ban. This second explanation motivates the empirical strategy we employ, with interacted fixed effects by time and countrypair. Including country or country-pair fixed effects means we identify the effect of the Convention or Ban based on changes to signatory status within countries or country-pairs over time, rather than from comparisons across signatories and non-signatories in any given year. 
In fact, waste volumes among all countries have been growing so much that these crosssection differences in Table 3 may be obscured by overall growth. Figure 2 shows that between 1988 and 2008, waste trade has grown by many multiples, and that waste imported into non-A7 countries accounts for nearly half of that growth. Notably, shipments from A7 to non-A7 countries - the shipments prohibited by the Ban - account for more than a quarter of the overall growth in waste trade. Given that the number of countries that ratified the Convention and the Ban grew significantly over the period, it seems likely that signatory status is endogenous with changes in waste trade - non-A7 countries experiencing large increases in imports, for example, may be more likely to sign the Ban.

To get a better idea of the importance of shipments from A7 to non-A7 countries, in Figure 3 we plot average bilateral waste flows conditional on Basel ratification status. The result is striking. When the A7 and non-A7 countries have both ratified the Convention, average bilateral waste shipments remain fairly constant over the 21 year period. However, when one or both are not ratified members of the Convention, the average volume of bilateral waste flows between countries increases by a factor of five. This is consistent with the top panel of Table 3 , where in column (2) annual A7 to non-A7 shipments from Basel signatories (rows 2 and 4) are far smaller than shipments from exporters that have not signed (rows 1 and 3), and makes it seem as though the Convention succeeded in reducing international waste shipments to non-A7 countries.

Although Figure 3 looks as though Basel has succeeded, that could be an artifact of the composition of countries signing the Convention. The growing difference between the waste shipments among Basel signatories and non-signatories depicted in Figure 3 combines two possible changes: (i) a real effect of the Convention on participants, reducing waste shipped 
among participants relative to waste shipped among non-participants; and (ii) a change in the composition of participants over time. This second effect is a form of selection bias. If countries trading the most waste ratify Basel first, and if over time the countries joining the Convention are those trading relatively less, then the average annual waste shipped among signatories might be declining, even if countries maintain the same patterns of trade regardless of their participation. In other words, the growing difference between signatories and non-signatories may be explained by the uneven sample of countries ratifying the Convention, rather than the effect of the convention on participants.

Figure 4 demonstrates this selection bias. It reports the average annual waste exports and imports over the entire 21-year period, plotted against the year in which the countries signed the Convention. Countries that joined Basel in 1992 exported an average of 1.5 million tons per year between 1988 and 2008. But countries that signed in 2000 exported an average of only 390 thousand tons. The average waste exports of Basel signatories are shrinking in part because the countries that joined the Convention later export less waste. The same is true for imports average waste imported by signatories declines because later signatories are lower-volume importers. A figure drawn for countries ratifying the Ban looks similar: those ratifying the Ban most recently export and import the least. If we are not careful, we could mistake this selection of countries into the Convention and Ban for the causal effect of those agreements.

To address this selection problem, Table 4 presents averages for country pairs where at some point between 1988 and 2008 one of the countries ratified the Convention. For example, the first row presents average annual waste shipments between countries where the exporter signed the Convention. After exporters signed it, exports to both A7 and non-A7 countries rose. The same is true for country pairs where the importer signed the Convention, and also in row (3) 
where at some point during the 21-year period the second of the two countries signed the convention.

Comparing Figure 3 and Table 4 reveals a stark fact. Figure 3 shows that from 1988 to 2008, waste shipments from A7 to non-A7 were smaller and grew less quickly when both of the countries were Basel signatories, seemingly in accordance with the agreement's intent. But Table 4 shows that this difference is driven in large part by the timing and selection of countries signing the Convention. Whether or not the importer, the exporter, or both signed the Convention, waste shipments were larger after signing than before, seemingly in violation of the agreement's intent.

Recall, however, that very few countries trading waste during this period were not Basel signatories, and that international waste trade in general increased steeply. Because of that, we also examine the Ban amendment. Rows (4)-(6) of Table 4 provide similar evidence suggesting the Ban has been ineffective. After A7 exporters signed the Ban, average waste exports to nonA7 countries doubled (to 34 thousand tons); after non-A7 waste importers signed the Ban, average waste imports more than tripled (to 136 thousand tons).

What's going on here? The most plausible explanation is that the overall growth in worldwide waste trade depicted in Figure 2 swamps any effect of the agreements. To identify the effect of the Basel Convention or Ban, we need to know whether the growth in A7 to non-A7 waste shipments was lower among signatories than it would have been absent their participation, not whether it was lower in absolute terms. That is a much more difficult question to answer, but one that our rich panel of waste-trade data can help address.

As a final piece of descriptive evidence, examine Figure 5, which plots average annual waste shipments from A7 to non-A7 countries. Instead of calendar years on the bottom axis, 
however, we have plotted the years relative to the year in which Basel or the Ban was signed. Figure 5a plots data for exporters. During the four years before A7 exporters signed the Ban, total waste shipments to non-A7 countries grew steadily, and during the four years after A7 exporters signed the Ban, waste shipments to non-A7 countries continued to grow steadily at approximately the same rate. Figure $5 \mathrm{~b}$ plots those same series for importers. Imports of waste rose steadily both before and after the importing country signed the Ban.

All of this descriptive material might be taken as evidence that the Basel Convention and Ban did not reduce waste shipments from developed to developing countries. This would be consistent with most of the theoretical and existing empirical research on IEAs. Any such conclusions, however, must be tempered by two caveats. First the descriptive evidence controls for nothing about countries aside from whether or not they join the Convention or the Ban. We know from the large empirical trade literature that countries' characteristics such as their distance from one another and the size of their populations and economies are highly correlated with international trade. Second, and perhaps more importantly, participation in these IEAs seems likely to be endogenous. If countries receiving or expecting to receive growing quantities of waste respond by signing Basel or the Ban, that may mask the effect of those IEAs on what waste trade would have been absent their participation.

As a consequence, the next step is to estimate the effect of the Basel Convention and Ban on waste trade holding those other country characteristics constant, and attempting to control for the potential endogeneity of countries' participation in the treaty. 


\section{Gravity-Model Tests of the Basel Convention and Ban Amendment}

To examine the effects of the Basel Convention and Ban on international waste shipments, we estimate a version of the standard "gravity" model of international trade, where instead of goods trade we substitute our measure of waste shipments. ${ }^{14}$

$$
\begin{aligned}
\ln X_{i j t}= & \boldsymbol{\beta}_{\mathrm{t}}+\beta_{1}\left(\ln \text { GDP }_{i t}\right)+\beta_{2}\left(\ln \text { GDP }_{j t}\right)+\beta_{3}\left(\ln \text { Distance }_{i j}\right)+\beta_{4}\left(\text { Border }_{i j}\right) \\
& +\beta_{5}\left(\text { Language }_{i j}\right)+\beta_{6}\left(\text { Colony }_{i j}\right)+\beta_{7}\left(\text { Basel }_{i t}\right)+\beta_{8}\left(\text { Basel }_{j t}\right)+\beta_{9}\left(\text { Basel }_{i j t}\right) \\
& +\beta_{10}\left(\text { FTA }_{i j t}\right)+\beta_{11}\left(\text { WTO }_{i j t}\right)+\beta_{12}\left(\text { nonA7toA }_{i j}\right)+\beta_{13}\left(\text { A7toA }_{i j}\right) \\
& +\beta_{14}\left(\text { A7tononA }_{i j}\right)+\beta_{15}\left(\text { Ban }_{i t}\right)+\beta_{16}\left(\text { Ban }_{j t}\right)+\beta_{17}\left(\text { Ban }_{i j t}\right) \\
& +\beta_{18}\left(\text { A7tononA }_{i j} \times \text { Ban }_{j t}\right)+\beta_{19}\left(\text { A7tononA }_{i j} \times \text { Ban }_{i t}\right) \\
& +\beta_{20}\left(\text { A7tononA7 }_{i j} \times \text { Ban }_{i j t}\right)+\varepsilon_{i j t},
\end{aligned}
$$

The dependent variable is the log of waste shipments, in tons, from country $i$ to country $j$ in year $t\left(X_{i j t}\right)$. Each country pair can appear twice per year, once each for shipments in both directions.

This is regressed on exporter fixed effects $\left(\boldsymbol{\beta}_{\mathrm{i}}\right)$, importer fixed effects $\left(\boldsymbol{\beta}_{\mathrm{j}}\right)$, and year fixed effects

$\left(\boldsymbol{\beta}_{\mathrm{t}}\right)$; the $\log$ of the real GDP of countries $i$ and $j$ in year $t$, the log of the distance between countries $i$ and $j$, and whether countries $i$ and $j$ share a border, a common official language, or have ever had colonial ties; dummy variables indicating if countries $i$ and $j$ were ratified members of the Basel Convention or the Ban Amendment in year $t\left(\right.$ Basel $_{i}$, Basel $_{j}$, Ban $_{i t}$, Ban $\left._{j t}\right)$, as well as the interactions (Basel $l_{i j t}$ Ban $_{i j t}$ ), indicating that both countries were ratified members; and dummy variables indicating whether countries $i$ and $j$ are members of the WTO or some other Free Trade Area or Customs Union in year $t\left(W T O_{i j t}, F T A_{i j t}\right)$. Table 5 presents descriptive statistics for the right-hand-side variables in equation (1).

\footnotetext{
${ }^{14}$ The model is grounded in the theoretical monopolistic competition models first developed by Anderson (1979) and Bergstrand (1985) and later extended to account for multilateral resistance terms (Anderson and van Wincoop, 2003) and heterogeneous firms (Helpman, Melitz, and Rubenstein, 2008). Our approach extends Baggs' (2009) panel application of the Helpman et al. (2008) model to international trade in hazardous waste by explicitly accounting for endogeneity concerns arising from a variety of unobserved omitted variable biases.
} 
To account for differences in general bilateral trade flows among and between A7 and non-A7countries, we also include three additional dummy variables: A7toA7 $i j ;$ A7tononA $7_{i j}$; and nonA7toA $7_{i j}$. Shipments among non-A7 countries are the omitted category. We capture the effect of ratification of the Ban Amendment on A7 to non-A7 waste flows by interacting the A7tononA $7_{i j}$ dummy with the $B a n_{i t}$ dummy to get $A 7 B$ tononA $7_{i j t}$. Notice that this dummy variable is time-varying and country-pair-specific. The coefficient $\beta_{20}$ tells us whether there is any difference in bilateral waste trade from A7 countries to non-A7 countries when the A7 exporting country has ratified the Ban Amendment relative to when the A7 country has not ratified the Ban Amendment, controlling for other country characteristics.

Table 6 presents estimates of different versions of equation (1). Columns (1) and (2) include only the time fixed effects - no country-specific fixed effects. The results confirm that in this new context of waste shipments, the gravity model has explanatory power typical of empirical models of trade in goods. More waste is shipped among countries that have higher GDP, are closer together, share a common border or colonial history, and are members of the WTO or other trade agreements.

Columns (1) and (2) also contain indicator variables for annual country pairs where the exporter, the importer, or both countries have signed the Basel Convention or the Ban. The Basel indicators are all negative and statistically significant in the cases where the exporter is a signatory. Interpreted literally, the point estimates (-0.403 and -0.421) mean that trade flows are 33 percent lower when the exporting country has signed the Basel Convention. ${ }^{15}$ Similarly, the coefficient in column (1) on the indicator for the exporting country having ratified the Ban Amendment (-0.494) suggests that in those cases, waste exports are 39 percent lower. Column

\footnotetext{
${ }^{15}$ This interpretation of dummy coefficients in semilog equations is from Kennedy (1981). The percentage change can be approximated as $100[\exp (c-1 / 2 v))-1]$, where $c$ is the estimated coefficient on the dummy variable and $v$ is that estimate's variance.
} 
(2) differs from column (1) in that it includes an interaction between the Ban indicator variables and cases where the observation involves a shipment from an A7 exporter to a non-A7 importer. That coefficient (-0.401) is also large and statistically significant, implying that the Ban is associated with a 33 percent drop in waste trade in that prohibited situation.

These results in columns (1) and (2) mirror the descriptive statistics in Table 3. They cannot be interpreted as a causal effect of the Convention or the Ban on international waste shipments, because we know that waste trade grew voluminously during this period, that large exporters and importers were among the first to sign the Convention and the Ban, and that countries decisions to ratify either treaty were likely endogenous with respect to their waste shipments. In fact, there are signs of this endogeneity in columns (1) and (2). The coefficient on "Ban both" - a dummy equal to one if both the exporter and importer have ratified the Ban - is positive and statistically significant, and suggests that when both countries have signed, waste shipments are one-third larger, exactly the opposite of the treaty's intent. It could be that waste exporters are more likely to sign the Ban if they know their waste exports are declining anyway, or that waste importers are more likely to sign if they experience large increases. In other words, we don't know whether the percent declines were caused by the treaty or if they would have occurred without it - we don't know the counterfactual. For those reasons, in columns (3)-(6) of Table 6 we attempt to address those sources of bias with country-year and country-pair fixed effects.

More formally, the error term $\varepsilon_{i j t}$ in equation (1) may include unobserved time-varying exporter and importer characteristics that influence bilateral trade from country $i$ to country $j$,

$$
\varepsilon_{i j t}=\omega_{i t}+\omega_{j t}+e_{i j t}
$$


The terms $\omega_{i t}$ and $\omega_{j t}$ would include any unobserved characteristics that are country-specific and change over time, but are not specific to a bilateral trading pair $i j$. Examples might include timevarying importer and exporter-specific multilateral price terms (Anderson and van Wincoop, 2003), environmental regulations and recycling costs (Kellenberg, 2012), capital-labor ratios (Baggs, 2009), political environments (Grossman and Helpman, 1994), or firm-level heterogeneity due to the fixed costs of exporting (Helpman, Meltiz, and Rubenstein, 2008). These are all potentially correlated with both waste trade flows among country-pairs and the probability that countries ratify the Convention or Ban, and therefore represent a possible source of omitted variable bias.

\section{Exporter and Importer-Year Fixed Effects}

To account for time-varying, country-specific omitted variables ( $\omega_{i t}$ and $\left.\omega_{j t}\right)$, columns (3) and (4) of Table 6 add importer-year and exporter-year fixed effects

$$
\ln X_{i j t}=\boldsymbol{\beta}_{\mathrm{it}}^{\boldsymbol{\theta}}+\boldsymbol{\beta}_{\mathrm{jt}}^{\boldsymbol{\theta}}+\ldots
$$

where all time-varying exporter and importer-specific characteristics in year $t$ are now captured by the coefficients $\boldsymbol{\beta}_{\mathbf{i t}}^{\boldsymbol{\theta}}$ and $\boldsymbol{\beta}_{\mathbf{j t}}^{\boldsymbol{\theta}}$. Any country-year-specific variables drop out, including GDP and membership in the Basel and Ban agreements, because they are collinear with the fixed effects $\boldsymbol{\beta}_{\mathbf{i t}}^{\boldsymbol{\theta}}$ and $\boldsymbol{\beta}_{\mathbf{j} \mathbf{t}}^{\boldsymbol{\theta}}$. What remains are characteristics that are bilateral-specific, such as distance, common language, and whether both countries are members of the Convention ${ }^{16}$ and Ban.

In column (3) of Table 6 the Basel both coefficient is small and statistically insignificant, and the Ban both coefficient (0.218) retains its counterintuitive positive sign, suggesting that when both countries ratify the Ban waste shipments are 25 percent larger. Column (4) adds the

\footnotetext{
${ }^{16}$ For example, France's ratification of the Convention is perfectly collinear with France's importer-year and exporter-year dummies, but in any given year France may ship waste to and from countries that may or may not also be members of the Convention, so the dummy "Basel both" remains identified.
} 
interaction term with the indicator for A7-to-non-A7 shipments. Here we include the interacted term with indicators for whether the exporter or importer has signed the Ban. The fixed effects don't absorb that variation, because exporters ship to both A7 and non-A7 countries in any given year, and so the interaction term varies within country-years. The key coefficient for when the exporter signs the Ban (-0.409) remains large and statistically significant, suggesting a waste decline of 33 percent. Meanwhile the counterintuitive coefficient on both countries signing the Ban (0.140) has declined significantly, implying a 15 percent waste increase, and that coefficient is tiny and insignificant for the A7-to-non-A7 shipments. ${ }^{17}$

Despite the addition of country-year-specific fixed effects, the negative interaction coefficient of the Ban exporter indicator could still be spurious if countries are more likely to sign the Ban if they have shrinking relative waste shipments to non-A7 countries. The reason countries join the Convention or ratify the Ban may involve their historical relationships with particular trading partners, rather than their own country characteristics. In that case unobserved bilateral relationships in the error term are correlated with waste shipments and IEA membership and may bias our estimates. In other words, columns (3) and (4) of Table 6 are still open to concerns about omitted variable bias, in which case they would still not answer our central question - whether countries that sign the Convention or the Ban experience declines in waste trade relative to what they otherwise would have experienced. To answer that question, we need an empirical strategy that identifies the relevant coefficients before and after one of the parties signs the Convention or Ban.

Columns (5) and (6) of Table 6 address this last concern by including country-pair specific fixed effects in equation (2),

\footnotetext{
${ }^{17}$ One possible explanation for these counterintuitive coefficients involves waste being rerouted from A7 Ban signatories to non-A7 countries via third-parties - other A7 countries that have not signed the Ban. We explore evidence for that in the penultimate section of the paper.
} 


$$
\begin{aligned}
\ln X_{i j t}= & \boldsymbol{\beta}_{\mathrm{it}}^{\boldsymbol{\theta}}+\boldsymbol{\beta}_{\mathrm{jt}}^{\boldsymbol{\theta}}+\boldsymbol{\beta}_{\mathrm{ij}}^{\boldsymbol{\theta}}+\beta_{9}\left(\text { Basel }_{i j t}\right)+\beta_{12}\left(W T O_{i j t}\right)+\beta_{13}\left(F T A_{i j t}\right) \\
& +\beta_{19}\left(\text { Ban }_{i j t}\right)+\beta_{20}\left(\text { A BtononA }_{i j t}\right)+\varepsilon_{i j t} .
\end{aligned}
$$

This is the approach taken by Baier and Bergstrand (2007), and in this context it controls for all characteristics that could possibly be correlated with annual waste shipments among countries, other than those that are both time-varying and country-pair-specific.

The general idea behind these country-pair fixed effects is illustrated by the bottom half of Table 4, discussed earlier. The first cell in row (4) contains the average bilateral waste shipments $\left(X_{i j t}\right)$ from $\mathrm{A} 7$ to other A7 countries where the exporter has not yet signed the Ban (88 thousand tons). Column (3) contains those pre-ratification shipments to non-A7 countries. The difference is 71,222 (not shown in the table), which is large and statistically significant. Columns (2) and (4) contain those same figures after the exporting A7 country has signed the Ban. That difference $(70,983)$ is also large and significant, but only insignificantly smaller. That differencein-differences is not only statistically insignificant, but goes in the wrong direction. The Ban should have increased the difference between shipments to A7 and non-A7 countries, not decreased it. Looked at differently, row (4) shows that after exporters signed the Ban, shipments to A7 countries grew by 17,051 tons, while shipments to non-A7 countries grew by 17,290 tons. In fact, in percentage terms the shipments to non-A7 countries grew by much more than shipments to A7 countries. Again, if the Ban were effective, we would expect shipments to nonA7 countries to have gone down relative to A7 countries, not up. It may be that Table 4 simply does not account for other covariates also correlated with waste trade and Ban participation. To estimate that difference-in-differences conditional on covariates, we run various versions of equation (3) in the last two columns of Table 6.

In columns (5) and (6) of Table 6 we estimate equation (3). Here any variables that either vary over time for a single country (GDP, treaty ratification) or are fixed over time for a single 
country-pair (distance, A7 or non-A7 status) are absorbed by the combination of country-year and country-pair fixed effects. None of the policy variables are statistically significant. The coefficient on both countries signing the Ban (0.059) implies that the average waste shipped among countries that both sign is 6 percent higher relative to that same country-pair before both had signed, consistent with the difference-in-difference calculations from Table 4. Column (6) adds the interaction with A7-to-non-A7 shipments $\left(\beta_{20}\right)$. That coefficient $(-0.167)$ is negative, as expected, but it is small and statistically insignificant.

Before we can be certain that neither the Basel Convention nor the Ban Amendment affected international waste shipments, we must be certain that our proxy for waste trade - the UN Comtrade data - does not contain too many categories of waste not deemed hazardous by the treaty.

Alternative measures of waste shipments

One potential explanation for why the Basel Convention and the Ban Amendment does not entirely eliminate waste shipments is the discrepancy between wastes categorized as "hazardous" by the Basel Convention, and trade listed as "waste" by the tariff system. As an alternative, we use the narrower definition of hazardous trade in Table A2, 20 product categories that are more likely than our original 60 categories in Table A1 to be completely composed of wastes considered hazardous under the Basel Convention.

The qualitative results in Table 7 are very much in line with those using the broader measure of waste trade. In columns (1) and (2), where we include only the year fixed effects, the coefficients on the indicators for when the exporter has signed the Basel Convention (-0.470 and -0.487 ) are again large, negative, and significant. But this time the coefficients on the indicators for when the importers sign Basel are also large, positive, and significant. Combined with the 
large coefficient on the indicator for both countries signing the Ban Amendment, this suggests that signing the treaty is an endogenous consequence of waste trade. Recall that in Table 3, there was no systematic pattern in average waste flows among countries that did and did not sign the Convention or the Ban.

Columns (3) and (4) of Table 7 add the importer-year and exporter-year fixed effects, as was done in Table 6. The Basel coefficients are insignificant and small, and the Ban coefficients are positive for both countries signing (0.476 and 0.422 ), and negative for trade between A7 and non-A7 countries when the exporter signs the Ban (-0.433). As in Table 6, one possibility is that treaty ratification is still endogenous; countries expecting to increase waste shipments are less likely to participate.

Columns (5) and (6) of Table 7 add the bilateral country-pair fixed effects, identifying the effects of the treaty from changes in participation within country-pairs when one or both of the countries signs. The coefficient on both countries participating in the Convention $(0.384$ and 0.375), are positive and significant, implying that waste shipments are 48 percent higher when both countries have signed. One possible explanation for this outcome is that the Convention restricts signatories from trading with non-signatories. So within country-pairs, when only one member is a Basel signatory, waste trade is restricted. When the second member joins, and the "Basel Both" indicator switches from zero to one, waste trade is unrestricted. In that sense, the outcome may be the intentional consequence of the treaty - increasing waste trade among signatories where it is monitored and regulated while decreasing trade among non-signatories where it is not.

Column (6) adds the interaction of the Ban Amendment with the indicator for A7-to-nonA7 shipments. This offers one small piece of evidence supporting the efficacy of this treaty. The 
coefficient on importers signing the Ban (-0.618) implies that waste shipments to non-A7 countries are 44 percent lower when the non-A7 importer has signed the Ban. This finding however, is not necessarily evidence of cooperative behavior among countries participating in an IEA. If it were, we should have found the strongest declines in bilateral waste trade occurring when both countries were members of the Ban. However, we found no evidence that participation by A7 countries, who are the largest waste exporters, had any effect on waste flows to developing countries. Rather, this result merely reflects non-cooperative behavior, where nonA7 countries make decisions regarding what's best for their own local environmental quality. When a non-A7 country commits to the Ban, highly toxic waste imports from A7 countries decline to that country. This result is consistent with Copeland (1991), who demonstrated that a small country that is unable or unwilling to enforce its own first best domestic environmental regulations, may make themselves better off by imposing an import ban on waste as a second best policy. It is not obvious, however, why an IEA such as the Ban would be necessary for that to happen.

\section{Trade Diversion: Waste Transshipped to non-A7 Countries}

One explanation for the lack of a decline in waste shipments in aggregate, or the decline in A7-to-non-A7 shipments in some cases, might be trade diversion. The Ban Amendment prohibits A7 signatories from shipping hazardous waste to any country outside of the A7 countries. Signatories can, however, ship waste to other A7 countries, whether or not the recipient has signed the Ban. If those shipments are in turn re-exported to non-A7 countries, that diversion would circumvent the intent of the Ban. The data we have enables us to examine 
whether hazardous waste is leaking from developed to developing countries through this loophole in the Ban.

Two trade patterns would betray evidence of waste being re-exported to circumvent the Ban. First, consider the originators of the waste. If there is diversion, A7 countries signing the Ban would ship more waste to A7 non-signatories than to A7 signatories, because the former would have the ability to re-export. Looking at the left side of Figure 6, shipments of type (iii) would be larger than type (i), or the difference between (iii) and (i) would be larger than the difference between (iv) and (ii), or that difference-in-differences would be larger after country A signs the Ban than before.

A second piece of evidence for trade diversion would involve the countries trans-shipping the waste through intermediary countries. If there is diversion, A7 countries that do not sign the Ban and that serve as trans-shippers would ship more waste to non-A7 countries the higher their imports of waste from A7 countries that did sign the Ban. Looking at the right side of Figure 6, shipments of type (vii) would be higher for countries of type D, the larger are its imports of type (iii) relative to imports of type (iv).

Start with the first pattern, shipments to trade-diverting countries. Figure 7 plots the share of waste shipped from A7 countries to A7 countries that have not ratified the Ban and are therefore possible intermediaries for shipments to non-A7 countries. The top line plots that share from A7 countries that signed the Ban at some point during the 21 year period; the bottom line represents countries that hadn't signed the Ban by $2008 .{ }^{18}$ The figure clearly shows that countries signing the Ban shipped a higher fraction of their waste to A7 countries that never signed the

\footnotetext{
${ }^{18}$ Note that we distinguish countries by whether they "ever" or "never" signed the Ban. If instead we distinguished countries by their current status, the percent waste would change over time for two reasons: the effect of the Ban and the composition of countries. Also, since the Ban did not exist before 1998, the top line would be 1.0 and the bottom line 0.0 for every year before then.
} 
Ban, but that they did so always, from before the Ban existed to after they signed. Moreover, for both groups - the ever-signed and the never-signed - the fraction shipped to non-ratifiers declines over time. If anything, the fraction shipped to non-ratifiers declines faster from the group signing the Ban. There seems to be no evidence in Figure 7 that ratifiers are circumventing the Ban by shipping more waste to the non-ratifying A7 countries.

What about the second pattern, shipments from trade-diverting countries? Figure 8 contains two scatterplots. The left-hand graph plots the percent of waste shipped to non-A7 countries against the percent of imports from non-ratifying A7 countries, for A7 countries that have not ratified the Ban. Using the scheme outlined in Figure 6, the left graph in Figure 8 plots shipments to and from country D, which hasn't signed the Ban. Each point represents exports of type (vii) divided by the sum of (vii) and (viii), on the left axis, against imports of type (iii) divided by the sum of (iii) and (iv), on the bottom axis. If non-ratifying A7 countries like D are serving as a loophole in the Ban, re-exporting waste from A7 ratifiers like A to non-A7 countries like E, we should see the percentage of waste shipped to non-A7 countries increase with the percentage of imports from ratifying A7 countries. Figure 8 shows that is not happening. If anything, the higher the share of imports from ratifying A7 countries, the lower the share of exports to non-A7 countries.

To double-check, on the right-hand side of Figure 8 we have drawn that same plot for A7 countries that have ratified the Ban. To be clear, exports by A7 ratifiers should be zero, but recall that our measure of trade merely proxies for hazardous waste as defined by Basel. So there are many positive observations, but there is also a mass of observations around $(1,0)$; when most of all imports come from A7 ratifiers, little or no waste is exported to non-A7 countries. 
In sum, the evidence based on patterns of imports by Ban signatories, and their exports to non-A7 countries, suggests there has been no significant circumvention of the Ban by nonsigners re-exporting waste to non-A7 countries. The treaty's apparent lack of effect is not the result of countries circumventing the treaty's intent by transshipping waste; it is the result of the treaty having had no effect at all on A7 exporters.

\section{Conclusions and Implications}

The theoretical and empirical economics literature to date is almost entirely skeptical about the efficacy of the IEAs that have proliferated worldwide over the past 30 years. Our results do not controvert that skepticism: IEAs appear to do little more than ratify what countries would have done absent the agreements. Before embarking on this study, we believed that empirical drawbacks in the existing studies might explain their failure to find that IEAs are effective. Data on international environmental problems are scarce for countries that do not participate in treaties, making before-and-after comparisons difficult, and existing work has a difficult time ascertaining what countries that ratify IEAs would have done absent the agreements. We address those problems by examining the Basel Convention using Comtrade data on international waste trade as a close approximation of the types of hazardous waste governed by Basel, and comparing waste exports before and after each country signs the Ban, holding constant existing trends and country characteristics with country-year and country-pair fixed effects. But despite the empirical advantages of our approach, we find almost no evidence to contradict that conventional skepticism. The Basel Convention and Ban seem to have had no effect on the growth of international hazardous waste, and almost no effect on shipments from developed to developing countries. 
Might our results have broader implications for other international problems? In some regards, global environmental issues such as climate change pose starkly different problems than hazardous waste trade. Climate change involves a global pollutant emitted at the location where goods are produced, whereas hazardous wastes are local pollutants that can be separated from the point of consumption or production and shipped globally. On one hand, that difference means that the world's hazardous waste problems are potentially solvable without international agreements, while the same is not true for climate change or other transboundary global pollutants. If all countries had efficient local environmental and waste disposal regulations, there might be no need for treaties like the Basel Convention and Ban. International waste trade would be efficient like any other imported or exported good. But transboundary pollution such as greenhouse gas emissions imposes a global externality, and so local governments will always have incentives to free-ride on other countries' abatement efforts. The fact that voluntary IEAs appear ineffective suggests that alternative policy mechanisms and strategies may need to be developed to solve large international environmental problems. 


\section{References}

Anderson, J., and E. van Wincoop, 2003, Gravity with Gravitas: A Solution to the Border Puzzle, American Economic Review, 93, 170-192.

Auffhammer, Maximilian, Bernard Morzuch, and John Stranlund. 2005. "Production of Chloroflurocarbons in Anticipation of the Montreal Protocol" Environmental and Resource Economics 2005 30(4), 377-391.

Baggs, Jen, 2009, International Trade in Hazardous Waste, Review of International Economics, 17(1), 1-16.

Baier, Scott and Jeffrey H. Bergstrand, 2007, Do free trade agreements actually increase members' international trade?, Journal of International Economics, 71(1), 72 - 95.

Barrett, Scott, 1994, Self-Enforcing International Environmental Agreements, Oxford Economic Papers, 46, 878-894.

Barrett, Scott, 1997a, Heterogeneous international environmental agreements, in C. Carraro (ed.) International Environmental Negotiations. Strategic Policy Issues, Edward Elgar, Cheltenham.

Barrett, Scott, 1997b, The strategy of trade sanctions in international environmental agreements, Resource and Energy Economics, 19, 345-361.

Brander, James and M. Scott Taylor, 1997. "International Trade and Open Access Renewable Resources: the small open economy case" Canadian Journal of Economics, 30: 526-552.

Bratberg, Espen, Sigve Tjøtta, and Torgeir Øines, 2005, Do voluntary international environmental agreements work?, Journal of Environmental Economics and Management, 50, 583-597.

Carraro, Carlo and Domenico Siniscalco, 1993, Strategies for the international protection of the environment, Journal of Public Economics, 52, 309-28.

Charnovitz, Steve, 2007, The WTO's Environmental Progress, Journal of International Economic Law, 10(3), 685-706.

Chichilnisky, Graciela, 1994. "North-South Trade and the Global Environment" American Economic Review, 84(4):851-874.

Cole, M.A., A.J. Rayner, and J.M. Bates. 1997. "The Environment Kuznetz Curve: An Empirical Analysis" Environment and Development Economics 2(4), 401-416.

Copeland, Brian, 1991. "International Trade in Waste Products in the Presence of Illegal Disposal," Journal of Environmental Economics and Management, 20: 143-162.

Ederington, Josh and Jenny Minier, 2003, Is Environmental Policy a Secondary Trade Barrier? An Empirical Analysis, Canadian Journal of Economics, 36(1), 137-154.

Finus, Michael and Stefan Maus, 2008, Modesty May Pay!, Journal of Public Economic Theory, 10(5), 801-826.

Finus, Michael and Sifve Tjøtta, 2003, The Oslo Protocol on sulfur reduction: the great leap forward?, Journal of Public Economics, 87, 2031-2048.

Helpman, Elhanan, Marc Melitz, and Yona Rubinstein, 2008, Estimating Trade Flows: Trading Partners and Trading Volumes, Quarterly Journal of Economics, 123(2), 441-87.

Kellenberg, Derek, 2012, "Trading Wastes" Journal of Environmental Economics and Management, 64(1), 68-87.

Kennedy, Peter E. 1981. "Estimation with Correctly Interpreted Dummy Variables in Semilogarithmic Equations" American Economic Review, 71(4), 801

Levinson, Arik, 1999, "NIMBY Taxes Matter: The Case of State Hazardous Waste Disposal Taxes" Journal of Public Economics, 74(1). 
Levinson, Arik, 2000, "State Taxes and Interstate Hazardous Waste Shipments" American Economic Review, 89(3) June 1999.

Martin, Will and Patrick Messerlin, 2007, Why is it so difficult? Trade Liberalization under the Doha Agenda, Oxford Review of Economic Policy, 23(3), 347-66.

McGinty, Matthew, 2007, International environmental agreements among asymmetric nations, Oxford Economic Papers, 59, 45-62.

Mitchell, Ronald B., 2002-2011, International Environmental Agreements Database Project (Version 2010.3). Available at: http://iea.uoregon.edu/. Date accessed: 5 April 2011.

Murdoch, James C. and Todd Sandler, 1997a, Voluntary Cutbacks and Pretreaty Behavior: The Helsinki Protocol and Sulfer Emissions, Public Finance Review, 25, 139-62.

Murdoch, James C. and Todd Sandler, 1997b, The voluntary provision of a pure public good: The case of reduced CFC emissions and the Montreal Protocol, Journal of Public Economics, 63, 31-349.

Pellow, David Naguib, 2007, Resisting Global Toxics: Transnational Movements for Environmental Justice, MIT Press, Cambridge, MA.

Puckett, Jim \& Ted Smith, Eds., 2002, Exporting Harm: The High-Tech Trashing of Asia, http://www.ban.org/E-waste/technotrashfinalcomp.pdf.

Puckett, Jim, Ed., 2005, The Digital Dump: Exporting Re-use and Abuse to Africa, http://www.ban.org/BANreports/10-24-05/documents/TheDigitalDump_Print.pdf.

Ringquist, Evan J. and Tatiana Kostadinova, 2005, Assessing the Effectiveness of International Environmental Agreements: The Case of the 1985 Helsinki Protocol, American Journal of Political Science, 49(1), 86-102.

Rose, Andrew K. and Mark M. Spiegel, 2009, Noneconomic Engagement and International Exchange: The Case of Environmental Treaties, Journal of Money, Credit, and Banking, 41(2-3), 337-363.

Shahin, Magda, 2009, To What Extent Should Labor and Environmental Standards Be Linked to Trade?, The Law and Development Review, 2(1), Article 2. 


\section{Table 1: Correlations among categories of waste}

\begin{tabular}{|c|c|c|c|}
\hline & $\begin{array}{c}\text { All } \\
\text { Comtrade }\end{array}$ & $\begin{array}{c}\text { Highly } \\
\text { hazardous }\end{array}$ & Basel data \\
\hline $\begin{array}{l}\text { All Comtrade waste } \\
\text { (Table A1) } \\
\text { Highly hazardous } \\
\text { Comtrade (Table A2) } \\
\text { Basel data }\end{array}$ & 1.00 & $\begin{array}{c}0.403 \\
n=14,194 \\
1.00\end{array}$ & $\begin{array}{c}0.507 \\
n=906 \\
0.367 \\
n=706 \\
1.00\end{array}$ \\
\hline
\end{tabular}

Table 2: Hazardous Waste Shipped Among Countries: 1988-2008

\begin{tabular}{|c|c|c|c|c|c|}
\hline & All & $\begin{array}{l}\text { A7 } \\
\text { to } A 7\end{array}$ & $\begin{array}{c}\text { A7 } \\
\text { to non-A7 }\end{array}$ & $\begin{array}{l}\text { Non-A7 } \\
\text { to } A 7\end{array}$ & $\begin{array}{l}\text { Non-A7 } \\
\text { to non-A7 }\end{array}$ \\
\hline & (1) & $(2)$ & (3) & (4) & (5) \\
\hline Total (million tons) & 2,163 & 1,295 & 456 & 202 & 211 \\
\hline Annual country-pairs & 46,149 & 13,531 & 10,083 & 11,864 & 10,671 \\
\hline $\begin{array}{l}\text { Average annual (tons) } \\
\text { (std. dev.) }\end{array}$ & $\begin{array}{r}46,865 \\
(304,563)\end{array}$ & $\begin{array}{c}95,670 \\
(420,143)\end{array}$ & $\begin{array}{c}45,178 \\
(363,328)\end{array}$ & $\begin{array}{c}17,001 \\
(121,229)\end{array}$ & $\begin{array}{r}19,775 \\
(177,567)\end{array}$ \\
\hline
\end{tabular}

Source: Authors' calculations from United Nations Comtrade data.

Note: "A7" refers to countries defined in Annex VII of the Basel Convention (all OECD and European Union countries plus Liechtenstein). Excludes 1241 observations where an importer or exporter only traded with one other country in a given year or where a pair of countries only traded in one year. 
Table 3: Tons of Hazardous Waste Shipped: By Basel Status 1988-2008

A7 to $\mathrm{A7}$

(1)

\section{By Basel Signatory Status}

1) Neither signs Basel

(std. dev.)

country-pairs

2) Exporter signs Basel

3) Importer signs Basel

4) Both sign Basel

\section{By Ban Signatory Status}

5) Neither signs Ban

6) Exporter signs Ban

7) Importer signs Ban

8) Both sign Ban
93,738

$(411,744)$

$\mathrm{n}=1224$

80,666

$(346,402)$

$\mathrm{n}=11,589$

94,021

$(411,193)$

$\mathrm{n}=11,518$

77,592

$(327,172)$

$n=10,800$

107,218

$(486,610)$

$\mathrm{n}=6,864$

99,089

$(367,869)$

$\mathrm{n}=4,749$

96,597

$(373,636)$

$\mathrm{n}=4,705$

131,501

$(437,559)$
A7 to non-A7

(2)

$$
\begin{gathered}
58,966^{*} \\
(176,232) \\
n=666 \\
29,623^{*} \\
(211,062) \\
n=8,654 \\
46,669^{*} \\
(395,194) \\
n=8,325 \\
30,231^{*} \\
(222,908) \\
n=7,561
\end{gathered}
$$

$34,166^{*}$

$(157,623)$

$\mathrm{n}=5,434$

$26,744^{*}$

$(156,542)$

$\mathrm{n}=3,787$

116,742

$(766,546)$

$\mathrm{n}=1,991$

$56,546^{*}$

$(263,246)$

$\mathrm{n}=1,129$

${ }^{*}$ Means in columns (1) and (2) statistically significantly different at 5 percent.

Note: The four categories in each panel are not mutually exclusive, and so do not sum to the totals in

Table 1. Excludes 1241 observations where an importer or exporter only traded with one other country in a given year or where a pair of countries only traded in one year. 
Table 4: Tons of Hazardous Waste Shipped:

Before and After Change in Basel Status 1988-2008

\begin{tabular}{|c|c|c|c|c|c|}
\hline & \multicolumn{2}{|c|}{$\mathrm{A} 7$ to $\mathrm{A} 7$} & \multicolumn{2}{|c|}{ A7 to non-A7 } \\
\hline & & Before & After & Before & After \\
\hline & & $(1)$ & $(2)$ & (3) & $(4)$ \\
\hline \multicolumn{6}{|c|}{ By Basel Signatory Status } \\
\hline 1) & $\begin{array}{l}\text { Exporter signs } \\
\text { Basel }\end{array}$ & $\begin{array}{c}61,502 \\
(273,188) \\
n=1,356\end{array}$ & $\begin{array}{c}105,826^{*} \\
(402,563) \\
n=5,741\end{array}$ & $\begin{array}{c}25,924 \\
(69,509) \\
n=665\end{array}$ & $\begin{array}{r}63,640^{*} \\
(332,765) \\
n=3,110\end{array}$ \\
\hline 2) & $\begin{array}{l}\text { Importer signs } \\
\text { Basel }\end{array}$ & $\begin{array}{c}88,779 \\
(387,287) \\
n=1451\end{array}$ & $\begin{array}{c}118,690^{*} \\
(482,552) \\
n=5,714\end{array}$ & $\begin{array}{c}24,361 \\
(94,547) \\
n=1233\end{array}$ & $\begin{array}{r}35,702^{*} \\
(129,617) \\
n=3765\end{array}$ \\
\hline 3) & $\begin{array}{l}\text { Both sign } \\
\text { Basel }\end{array}$ & $\begin{array}{c}61,579 \\
(264,983) \\
n=1,583\end{array}$ & $\begin{array}{c}90,837^{*} \\
(344,226) \\
n=6,026\end{array}$ & $\begin{array}{c}16,740 \\
(55,484) \\
n=1,253\end{array}$ & $\begin{array}{r}50,286 \\
(303,406) \\
n=3,754\end{array}$ \\
\hline \multicolumn{6}{|c|}{ By Ban Signatory Status } \\
\hline$\frac{5}{4)}$ & $\begin{array}{l}\text { Exporter signs } \\
\text { Ban }\end{array}$ & $\begin{array}{c}88,053 \\
(335,767) \\
n=4,546\end{array}$ & $\begin{array}{c}105,104^{*} \\
(378,181) \\
n=4,474\end{array}$ & $\begin{array}{c}16,831 \\
(58,036) \\
n=2,522\end{array}$ & $\begin{array}{r}34,121^{*} \\
(178,634) \\
n=2,869\end{array}$ \\
\hline 5) & $\begin{array}{l}\text { Importer signs } \\
\text { Ban }\end{array}$ & $\begin{array}{c}82,920 \\
(327,320) \\
n=4,288\end{array}$ & $\begin{array}{c}102,527^{*} \\
(384,231) \\
n=4,431\end{array}$ & $\begin{array}{c}42,009 \\
(205,640) \\
n=1,813\end{array}$ & $\begin{array}{c}135,781^{*} \\
(826,537) \\
n=1,706\end{array}$ \\
\hline 6) & Both sign Ban & $\begin{array}{c}103,313 \\
(362,361) \\
n=3,589\end{array}$ & $\begin{array}{c}137,006^{*} \\
(445,873) \\
n=2,674\end{array}$ & $\begin{array}{c}23,061 \\
(81,988) \\
n=1,269\end{array}$ & $\begin{array}{c}65,162 \\
(282,270) \\
n=975\end{array}$ \\
\hline
\end{tabular}

Each row contains only those bilateral pairs for which the row description is relevant.

For example, row 1 ("Exporter signs Basel") contains only bilateral pairs for which at some point during the 17 years, the Exporter signed Basel. Similarly, row 3 contains only bilateral pairs for which at some point the second of the two trading partners signed Basel.

*Means in columns (2) and (4) statistically significantly different from columns (1) and (3), respectively, at 5 percent. 
Table 5. Descriptive statistics

\begin{tabular}{|c|c|c|c|c|}
\hline & $\begin{array}{l}\text { A7 } \\
\text { to } \mathrm{A} 7\end{array}$ & $\begin{array}{c}\text { A7 } \\
\text { to non-A7 }\end{array}$ & $\begin{array}{l}\text { Non-A7 } \\
\text { to } A 7\end{array}$ & $\begin{array}{l}\text { Non-A7 } \\
\text { to non-A7 }\end{array}$ \\
\hline & $(1)$ & $(2)$ & (3) & $(4)$ \\
\hline $\begin{array}{l}\text { Average annual waste shipped } \\
\text { (tons) }\end{array}$ & $\begin{array}{c}95,670 \\
(420,142)\end{array}$ & $\begin{array}{c}45,178 \\
(363,328)\end{array}$ & $\begin{array}{c}17,001 \\
(121,229)\end{array}$ & $\begin{array}{c}19,775 \\
(177,567)\end{array}$ \\
\hline $\begin{array}{l}\text { Average high hazard waste } \\
\text { (tons) }\end{array}$ & $\begin{array}{c}4,768 \\
(20,371)\end{array}$ & $\begin{array}{c}2,509 \\
(21,210)\end{array}$ & $\begin{array}{c}639 \\
(1,887)\end{array}$ & $\begin{array}{c}1,394 \\
(6,597)\end{array}$ \\
\hline Importer GDP (billion 2000 \$) & $\begin{array}{c}996 \\
(2,050)\end{array}$ & $\begin{array}{c}225 \\
(403)\end{array}$ & $\begin{array}{c}1,471 \\
(2,414)\end{array}$ & $\begin{array}{c}265 \\
(449)\end{array}$ \\
\hline Exporter GDP (billion 2000 \$) & $\begin{array}{c}947 \\
(2,057)\end{array}$ & $\begin{array}{c}1,455 \\
(2,628)\end{array}$ & $\begin{array}{r}187 \\
(379)\end{array}$ & $\begin{array}{l}210 \\
(428)\end{array}$ \\
\hline Distance (km) & $\begin{array}{c}4,140 \\
(4,498)\end{array}$ & $\begin{array}{c}6,687 \\
(3,971)\end{array}$ & $\begin{array}{c}6,273 \\
(4,028)\end{array}$ & $\begin{array}{c}5,596 \\
(4,788)\end{array}$ \\
\hline Shared border & 0.092 & 0.035 & 0.035 & 0.165 \\
\hline Shared language & 0.086 & 0.142 & 0.129 & 0.315 \\
\hline Colonial ties & 0.056 & 0.067 & 0.074 & 0.017 \\
\hline Importer ratified Basel & 0.851 & 0.826 & 0.838 & 0.830 \\
\hline $\begin{array}{l}\text { Exporter ratified Basel } \\
\text { Importer ratified Ban }\end{array}$ & 0.856 & 0.858 & 0.784 & 0.856 \\
\hline $\begin{array}{l}\text { Amendment } \\
\text { Exporter ratified Ban }\end{array}$ & 0.348 & 0.197 & 0.322 & 0.207 \\
\hline Amendment & 0.351 & 0.376 & 0.175 & 0.212 \\
\hline Importer WTO member & 0.987 & 0.788 & 0.995 & 0.850 \\
\hline Exporter WTO member & 0.975 & 0.995 & 0.728 & 0.794 \\
\hline $\begin{array}{l}\text { Number of annual country pairs } \\
\text { Country pairs with highly } \\
\text { hazardous waste }\end{array}$ & $\begin{array}{r}13,531 \\
5,971\end{array}$ & $\begin{array}{r}10,083 \\
2,650\end{array}$ & $\begin{array}{r}11,864 \\
2,892\end{array}$ & $\begin{array}{r}10,671 \\
2,681\end{array}$ \\
\hline
\end{tabular}

Standard deviations in parentheses. 
Table 6: Basic Waste Regressions

\begin{tabular}{|c|c|c|c|c|c|c|}
\hline \multirow{2}{*}{$\begin{array}{l}\text { Dependent variable: } \\
\text { In(annual waste) }\end{array}$} & \multicolumn{2}{|c|}{ Year fixed effects } & \multicolumn{2}{|c|}{ Country-year fixed effects } & \multicolumn{2}{|c|}{ Bilateral fixed effects } \\
\hline & $(1)$ & $(2)$ & (3) & $(4)$ & (5) & (6) \\
\hline In(GDP exporter) & $\begin{array}{l}0.372^{*} \\
(0.008)\end{array}$ & $\begin{array}{l}0.369^{*} \\
(0.008)\end{array}$ & & & & \\
\hline In(GDP importer) & $\begin{array}{l}0.784^{*} \\
(0.009)\end{array}$ & $\begin{array}{l}0.785^{*} \\
(0.009)\end{array}$ & & & & \\
\hline Non $A 7$ to $A 7$ & $\begin{array}{l}-1.318^{*} \\
(0.040)\end{array}$ & $\begin{array}{l}-1.326^{*} \\
(0.040)\end{array}$ & $\begin{array}{c}9.89^{*} \\
(1.20)\end{array}$ & $\begin{array}{c}9.90^{*} \\
(1.20)\end{array}$ & & \\
\hline A7 to $A 7$ & $\begin{array}{l}-0.683^{*} \\
(0.046)\end{array}$ & $\begin{array}{l}-0.701^{*} \\
(0.046)\end{array}$ & $\begin{array}{l}15.70^{*} \\
(0.97)\end{array}$ & $\begin{array}{l}15.60^{*} \\
(0.97)\end{array}$ & & \\
\hline A7 to Non-A7 & $\begin{array}{l}-0.199^{*} \\
(0.043)\end{array}$ & $\begin{array}{l}-0.004 \\
(0.053)\end{array}$ & $\begin{array}{l}5.86^{\star} \\
(0.81)\end{array}$ & $\begin{array}{l}5.87^{*} \\
(0.81)\end{array}$ & & \\
\hline In(distance) & $\begin{array}{l}-1.001^{*} \\
(0.017)\end{array}$ & $\begin{array}{l}-1.000^{*} \\
(0.017)\end{array}$ & $\begin{array}{l}-1.799 \\
(0.020)\end{array}$ & $\begin{array}{l}-1.793^{*} \\
(0.020)\end{array}$ & & \\
\hline Common border & $\begin{array}{c}1.348^{\star} \\
(0.0535)\end{array}$ & $\begin{array}{c}1.350^{*} \\
(0.0535)\end{array}$ & $\begin{array}{c}1.201^{*} \\
(0.0485)\end{array}$ & $\begin{array}{c}1.210^{\star} \\
(0.0486)\end{array}$ & & \\
\hline Common language & $\begin{array}{l}-0.170^{\star} \\
(0.037)\end{array}$ & $\begin{array}{l}-0.178^{*} \\
(0.037)\end{array}$ & $\begin{array}{l}0.150^{*} \\
(0.037)\end{array}$ & $\begin{array}{l}0.151^{*} \\
(0.037)\end{array}$ & & \\
\hline Colony & $\begin{array}{l}0.722^{*} \\
(0.057)\end{array}$ & $\begin{array}{l}0.747^{*} \\
(0.057)\end{array}$ & $\begin{array}{l}0.939^{*} \\
(0.050)\end{array}$ & $\begin{array}{l}0.946^{*} \\
(0.050)\end{array}$ & & \\
\hline FTA & $\begin{array}{l}0.153^{*} \\
(0.036)\end{array}$ & $\begin{array}{l}0.139^{*} \\
(0.036)\end{array}$ & $\begin{array}{c}0.073 \\
(0.042)\end{array}$ & $\begin{array}{c}0.058 \\
(0.042)\end{array}$ & $\begin{array}{c}0.018 \\
(0.053)\end{array}$ & $\begin{array}{c}0.017 \\
(0.053)\end{array}$ \\
\hline WTO & $\begin{array}{l}0.236^{*} \\
(0.036)\end{array}$ & $\begin{array}{l}0.229^{*} \\
(0.036)\end{array}$ & $\begin{array}{c}0.201 \\
(0.118)\end{array}$ & $\begin{array}{c}0.200 \\
(0.118)\end{array}$ & $\begin{array}{l}0.0911 \\
(0.130)\end{array}$ & $\begin{array}{l}0.0852 \\
(0.130)\end{array}$ \\
\hline Basel importer & $\begin{array}{l}-0.119 \\
(0.093)\end{array}$ & $\begin{array}{l}-0.119 \\
(0.093)\end{array}$ & & & & \\
\hline Basel exporter & $\begin{array}{l}-0.403^{*} \\
(0.092)\end{array}$ & $\begin{array}{l}-0.421^{*} \\
(0.091)\end{array}$ & & & & \\
\hline Basel both & $\begin{array}{l}-0.195 \\
(0.101)\end{array}$ & $\begin{array}{l}-0.174 \\
(0.100)\end{array}$ & $\begin{array}{c}0.044 \\
(0.109)\end{array}$ & $\begin{array}{c}0.049 \\
(0.109)\end{array}$ & $\begin{array}{c}0.111 \\
(0.095)\end{array}$ & $\begin{array}{c}0.113 \\
(0.095)\end{array}$ \\
\hline Ban importer & $\begin{array}{l}-0.050 \\
(0.043)\end{array}$ & $\begin{array}{l}-0.015 \\
(0.044)\end{array}$ & & & & \\
\hline (Ban imp) X (A7tononA7) & & $\begin{array}{l}-0.135 \\
(0.122)\end{array}$ & & $\begin{array}{l}0.123 \\
(0.108)\end{array}$ & & $\begin{array}{c}0.130 \\
(0.117)\end{array}$ \\
\hline Ban exporter & $\begin{array}{l}-0.494^{*} \\
(0.041)\end{array}$ & $\begin{array}{l}-0.375^{*} \\
(0.046)\end{array}$ & & & & \\
\hline (Ban exp)X(A7tononA7) & & $\begin{array}{l}-0.401^{*} \\
(0.080)\end{array}$ & & $\begin{array}{l}-0.409^{*} \\
(0.079)\end{array}$ & & $\begin{array}{c}0.022 \\
(0.081)\end{array}$ \\
\hline $\begin{array}{l}\text { Ban both } \\
\text { (Ban both)X(A7tononA7) }\end{array}$ & $\begin{array}{l}0.286^{*} \\
(0.062)\end{array}$ & $\begin{array}{c}0.310^{*} \\
(0.068) \\
-0.300 \\
(0.171)\end{array}$ & $\begin{array}{l}0.218^{*} \\
(0.056)\end{array}$ & $\begin{array}{c}0.140^{*} \\
(0.063) \\
0.021 \\
(0.137)\end{array}$ & $\begin{array}{c}0.059 \\
(0.056)\end{array}$ & $\begin{array}{c}0.086 \\
(0.062) \\
-0.167 \\
(0.139)\end{array}$ \\
\hline Constant & $\begin{array}{l}9.15^{*} \\
(0.21) \\
\end{array}$ & $\begin{array}{l}9.15^{*} \\
(0.21)\end{array}$ & $\begin{array}{l}11.71^{*} \\
(0.91)\end{array}$ & $\begin{array}{l}11.62^{*} \\
(0.91)\end{array}$ & $\begin{array}{c}7.40^{*} \\
(1.00)\end{array}$ & $\begin{array}{c}7.69^{*} \\
(1.24)\end{array}$ \\
\hline Year f.e.'s & yes & yes & no & no & no & no \\
\hline Imp and exp-year f.e.'s & no & no & yes & yes & yes & yes \\
\hline Bilateral f.e.'s & no & no & no & no & yes & yes \\
\hline Observations & 46,149 & 46,149 & 46,149 & 46,149 & 46,149 & 46,149 \\
\hline R-squared & 0.265 & 0.267 & 0.576 & 0.576 & 0.814 & 0.814 \\
\hline
\end{tabular}

Robust standard errors in parentheses. ${ }^{*} p<0.05$.

Source: UN Comtrade Data, classified according to Appendix Table A1. 
Table 7: High Hazard Waste Regressions

\begin{tabular}{|c|c|c|c|c|c|c|}
\hline \multirow{2}{*}{$\begin{array}{l}\text { Dependent variable: } \\
\text { In(annual waste) }\end{array}$} & \multicolumn{2}{|c|}{ Year fixed effects } & \multicolumn{2}{|c|}{ Country-year fixed effects } & \multicolumn{2}{|c|}{ Bilateral fixed effects } \\
\hline & $(1)$ & $(2)$ & (3) & $(4)$ & $(5)$ & (6) \\
\hline $\ln ($ GDP exporter) & $\begin{array}{r}0.431^{*} \\
(0.014)\end{array}$ & $\begin{array}{r}0.429^{*} \\
(0.014)\end{array}$ & & & & \\
\hline In(GDP importer) & $\begin{array}{r}0.890^{*} \\
(0.017)\end{array}$ & $\begin{array}{l}0.886^{*} \\
(0.017)\end{array}$ & & & & \\
\hline Non-A7 to $A 7$ & $\begin{array}{l}-1.166^{*} \\
(0.080)\end{array}$ & $\begin{array}{l}-1.200^{*} \\
(0.080)\end{array}$ & $\begin{array}{r}8.260^{*} \\
(2.476)\end{array}$ & $\begin{array}{c}8.308^{*} \\
(2.467)\end{array}$ & & \\
\hline A7 to $A 7$ & $\begin{array}{l}-0.863^{*} \\
(0.080)\end{array}$ & $\begin{array}{l}-0.924^{*} \\
(0.079)\end{array}$ & $\begin{array}{l}12.26^{*} \\
(2.48)\end{array}$ & $\begin{array}{l}12.23^{*} \\
(2.47)\end{array}$ & & \\
\hline A7 to Non-A7 & $\begin{array}{l}0.0363 \\
(0.087)\end{array}$ & $\begin{array}{r}0.514^{*} \\
(0.106)\end{array}$ & $\begin{array}{l}4.369^{\star} \\
(0.470)\end{array}$ & $\begin{array}{r}4.497^{*} \\
(0.486)\end{array}$ & & \\
\hline In(distance) & $\begin{array}{l}-1.198^{*} \\
(0.029)\end{array}$ & $\begin{array}{l}-1.205^{\star} \\
(0.028)\end{array}$ & $\begin{array}{l}-1.726^{*} \\
(0.0340)\end{array}$ & $\begin{array}{l}-1.713^{*} \\
(0.034)\end{array}$ & & \\
\hline Common border & $\begin{array}{l}1.299^{\star} \\
(0.071)\end{array}$ & $\begin{array}{r}1.278^{*} \\
(0.070)\end{array}$ & $\begin{array}{l}1.142^{*} \\
(0.066)\end{array}$ & $\begin{array}{l}1.156^{*} \\
(0.066)\end{array}$ & & \\
\hline Common language & $\begin{array}{l}-0.002 \\
(0.060)\end{array}$ & $\begin{array}{l}-0.024 \\
(0.059)\end{array}$ & $\begin{array}{r}0.180^{*} \\
(0.061)\end{array}$ & $\begin{array}{r}0.165^{\star} \\
(0.062)\end{array}$ & & \\
\hline Colony & $\begin{array}{r}0.352^{*} \\
(0.085)\end{array}$ & $\begin{array}{r}0.449^{*} \\
(0.085)\end{array}$ & $\begin{array}{l}0.768^{*} \\
(0.073)\end{array}$ & $\begin{array}{l}0.794^{*} \\
(0.073)\end{array}$ & & \\
\hline FTA & $\begin{array}{l}-0.025 \\
(0.058)\end{array}$ & $\begin{array}{l}-0.057 \\
(0.057)\end{array}$ & $\begin{array}{l}-0.128 \\
(0.077)\end{array}$ & $\begin{array}{l}-0.144 \\
(0.077)\end{array}$ & $\begin{array}{l}-0.277^{*} \\
(0.087)\end{array}$ & $\begin{array}{l}-0.284^{*} \\
(0.087)\end{array}$ \\
\hline WTO & $\begin{array}{r}0.507^{*} \\
(0.078)\end{array}$ & $\begin{array}{r}0.510^{*} \\
(0.078)\end{array}$ & $\begin{array}{l}1.512^{*} \\
(0.352)\end{array}$ & $\begin{aligned} 1.564^{*} \\
(0.352)\end{aligned}$ & $\begin{array}{l}-0.778 \\
(0.449)\end{array}$ & $\begin{array}{l}-0.770 \\
(0.449)\end{array}$ \\
\hline Basel importer & $\begin{array}{r}0.468^{*} \\
(0.186)\end{array}$ & $\begin{array}{r}0.397^{*} \\
(0.181)\end{array}$ & & & & \\
\hline Basel exporter & $\begin{array}{l}-0.470^{*} \\
(0.182)\end{array}$ & $\begin{array}{l}-0.487^{*} \\
(0.176)\end{array}$ & & & & \\
\hline Basel both & $\begin{array}{l}-0.100 \\
(0.197)\end{array}$ & $\begin{array}{l}-0.033 \\
(0.191)\end{array}$ & $\begin{array}{c}0.230 \\
(0.196)\end{array}$ & $\begin{array}{c}0.206 \\
(0.196)\end{array}$ & $\begin{array}{c}0.384^{*} \\
(0.162)\end{array}$ & $\begin{array}{r}0.375^{\star} \\
(0.162)\end{array}$ \\
\hline Ban importer & $\begin{array}{l}-0.326^{*} \\
(0.077)\end{array}$ & $\begin{array}{l}-0.209^{*} \\
(0.077)\end{array}$ & & & & \\
\hline (Ban imp)X(A7tononA7) & & $\begin{array}{l}-0.536^{\star} \\
(0.246)\end{array}$ & & $\begin{array}{l}-0.392 \\
(0.225)\end{array}$ & & $\begin{array}{l}-0.618^{*} \\
(0.249)\end{array}$ \\
\hline Ban exporter & $\begin{array}{l}-0.549^{*} \\
(0.072)\end{array}$ & $\begin{array}{l}-0.333^{*} \\
(0.076)\end{array}$ & & & & \\
\hline (Ban exp)X(A7tononA7) & & $\begin{array}{l}-0.899^{*} \\
(0.156)\end{array}$ & & $\begin{array}{l}-0.433^{*} \\
(0.149)\end{array}$ & & $\begin{array}{l}-0.123 \\
(0.142)\end{array}$ \\
\hline $\begin{array}{l}\text { Ban both } \\
\text { (Ban both)X(A7tononA7) }\end{array}$ & $\begin{array}{c}0.596^{*} \\
(0.103)\end{array}$ & $\begin{array}{c}0.580^{*} \\
(0.105) \\
-0.750^{*} \\
(0.342)\end{array}$ & $\begin{array}{c}0.476^{*} \\
(0.100)\end{array}$ & $\begin{array}{l}0.422^{*} \\
(0.107) \\
-0.003 \\
(0.278)\end{array}$ & $\begin{array}{l}-0.083 \\
(0.087)\end{array}$ & $\begin{array}{c}-0.128 \\
(0.092) \\
0.452 \\
(0.288)\end{array}$ \\
\hline Constant & $\begin{array}{l}11.79^{*} \\
(0.32)\end{array}$ & $\begin{array}{r}11.83^{*} \\
(0.32)\end{array}$ & $\begin{array}{l}13.65^{*} \\
(2.42)\end{array}$ & $\begin{array}{c}13.40^{*} \\
(2.41)\end{array}$ & $\begin{array}{l}8.39^{*} \\
(0.57)\end{array}$ & $\begin{array}{r}8.92^{*} \\
(0.82)\end{array}$ \\
\hline Year f.e.'s & yes & yes & no & no & no & no \\
\hline Imp and exp-year f.e.'s & no & no & yes & yes & yes & yes \\
\hline Bilateral f.e.'s & no & no & no & no & yes & yes \\
\hline $\begin{array}{l}\text { Observations } \\
\text { R-squared }\end{array}$ & $\begin{array}{c}12,802 \\
0.392\end{array}$ & $\begin{array}{c}12,802 \\
0.400\end{array}$ & $\begin{array}{c}12,802 \\
0.724\end{array}$ & $\begin{array}{c}12,802 \\
0.724\end{array}$ & $\begin{array}{c}12,802 \\
0.922\end{array}$ & $\begin{array}{c}12,802 \\
0.923\end{array}$ \\
\hline
\end{tabular}

Robust standard errors in parentheses. ${ }^{*} p<0.05$

Source: UN Comtrade Data, classified according to Appendix Table A2. 
Figure 1

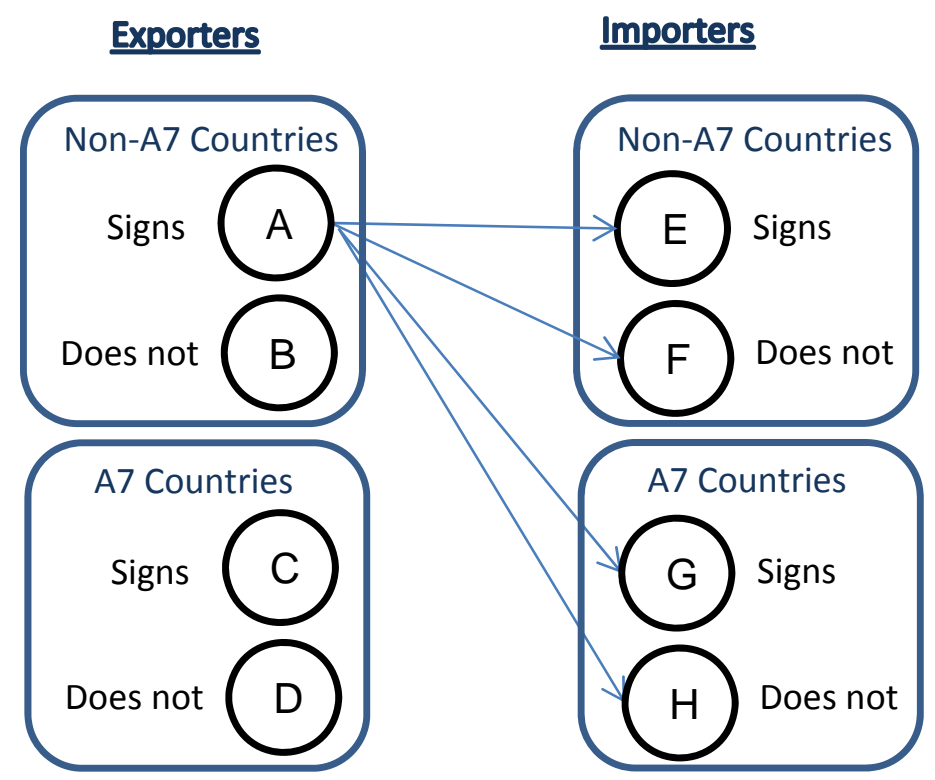

Figure 2

Total Annual Waste Shipments

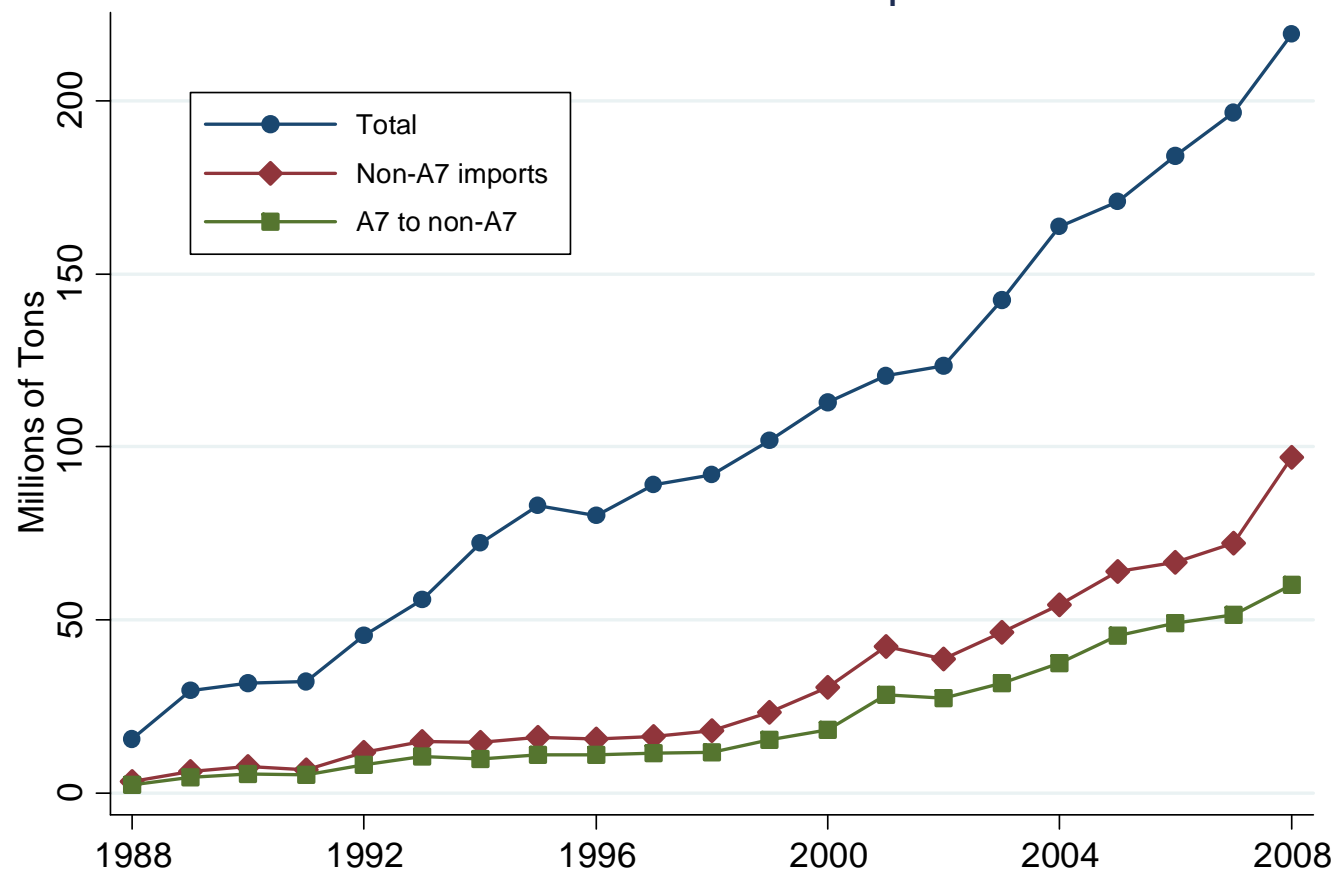


Figure 3

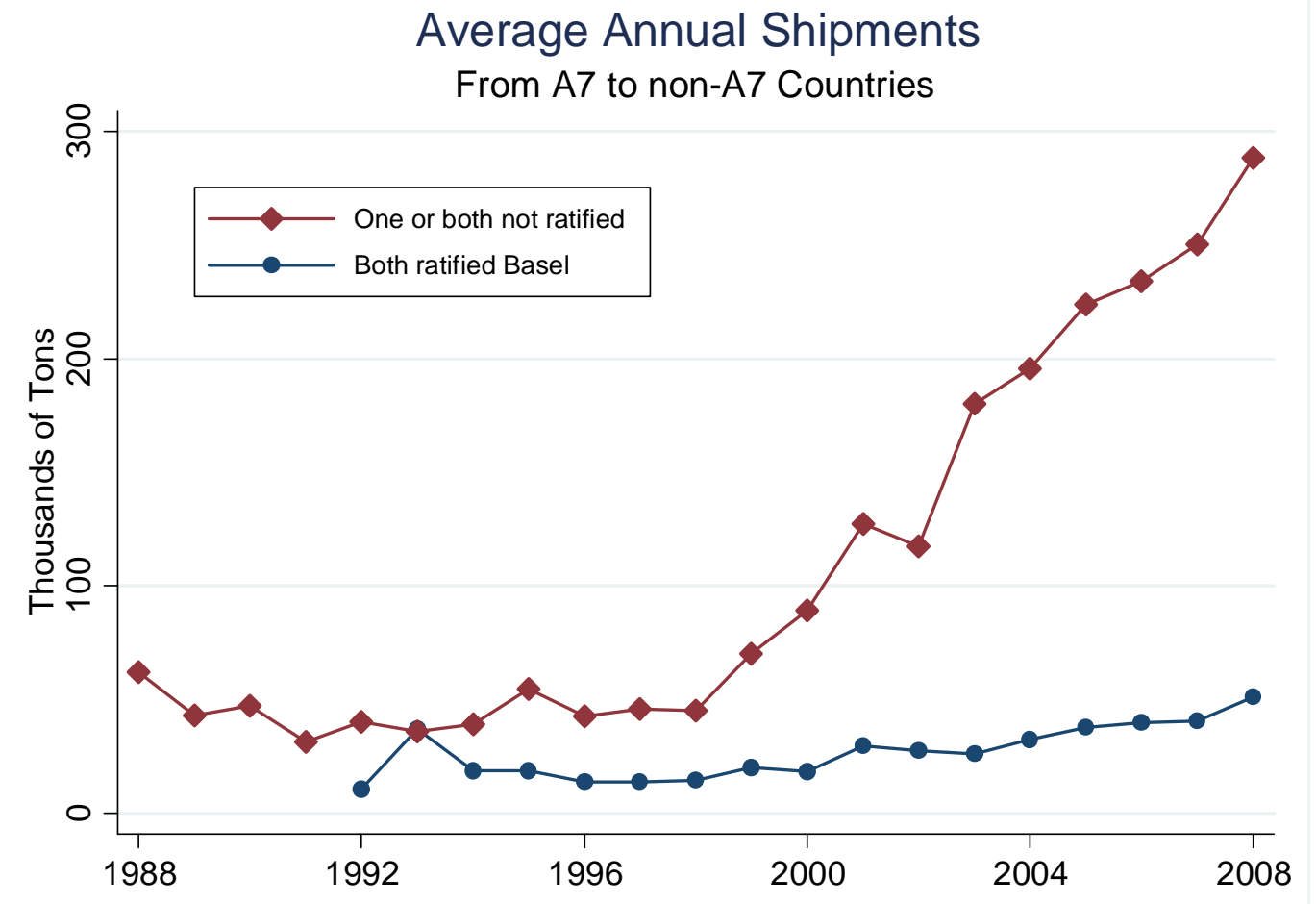

\section{Figure 4}

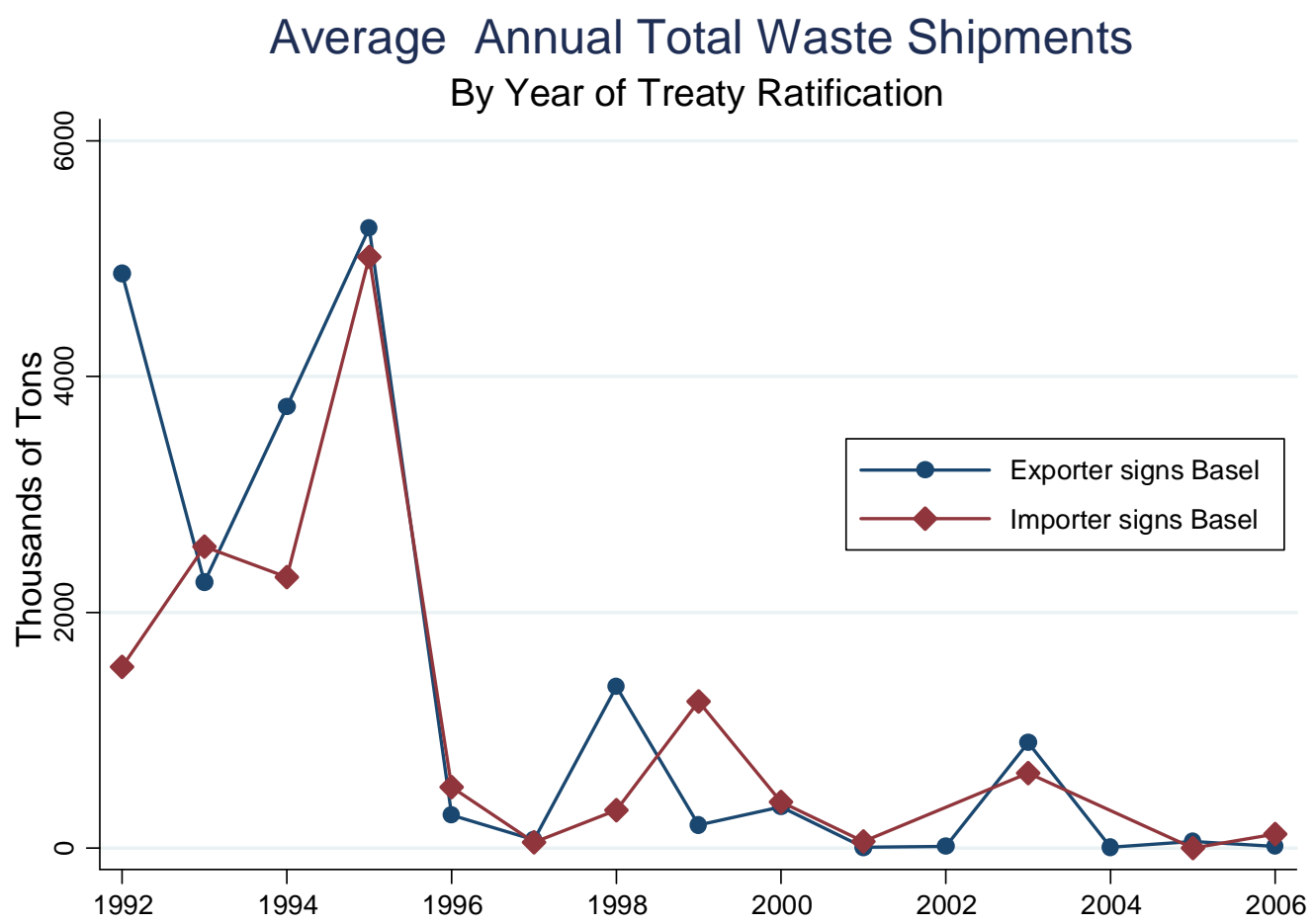




\section{Figure 5a}

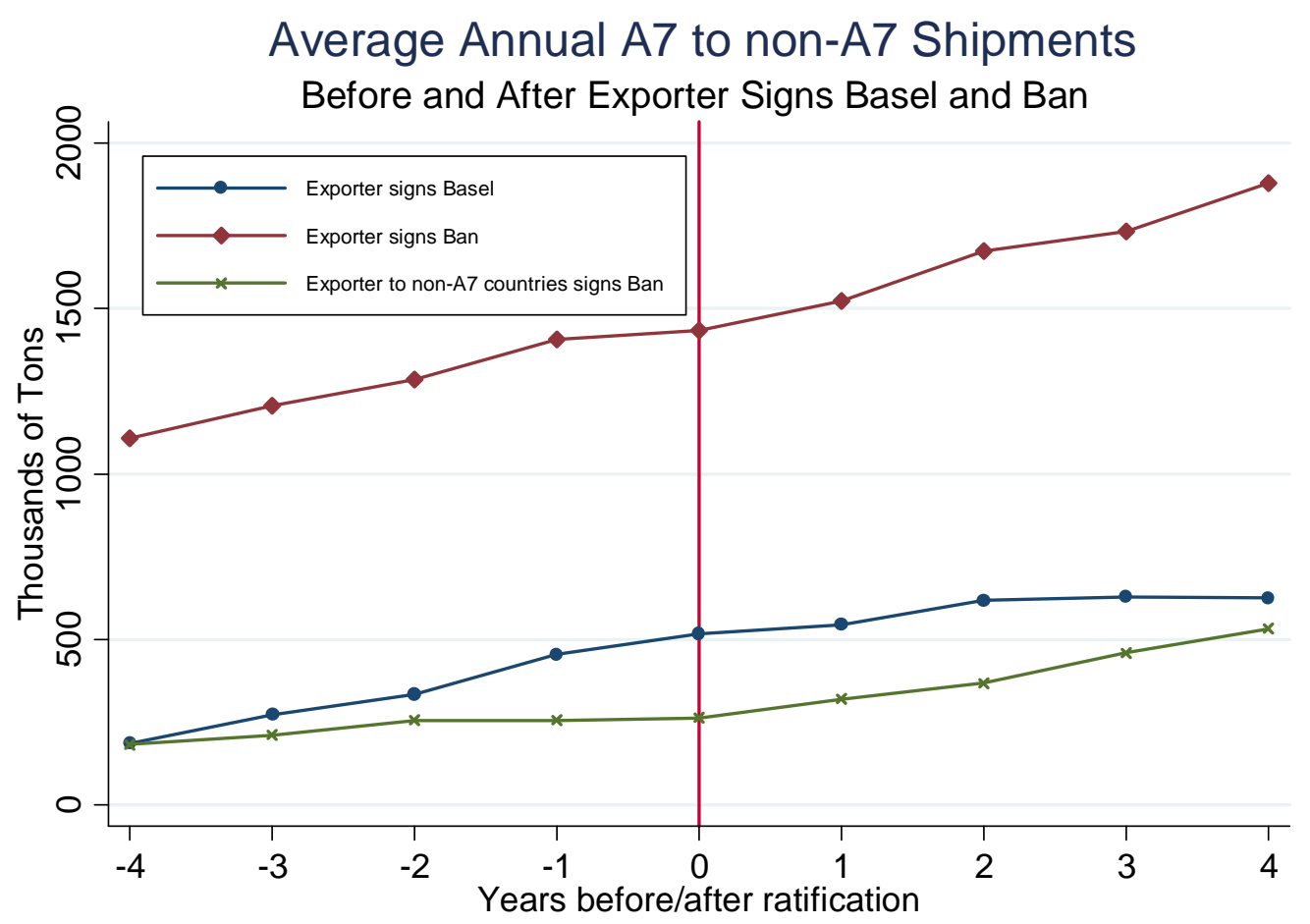

\section{Figure 5b}

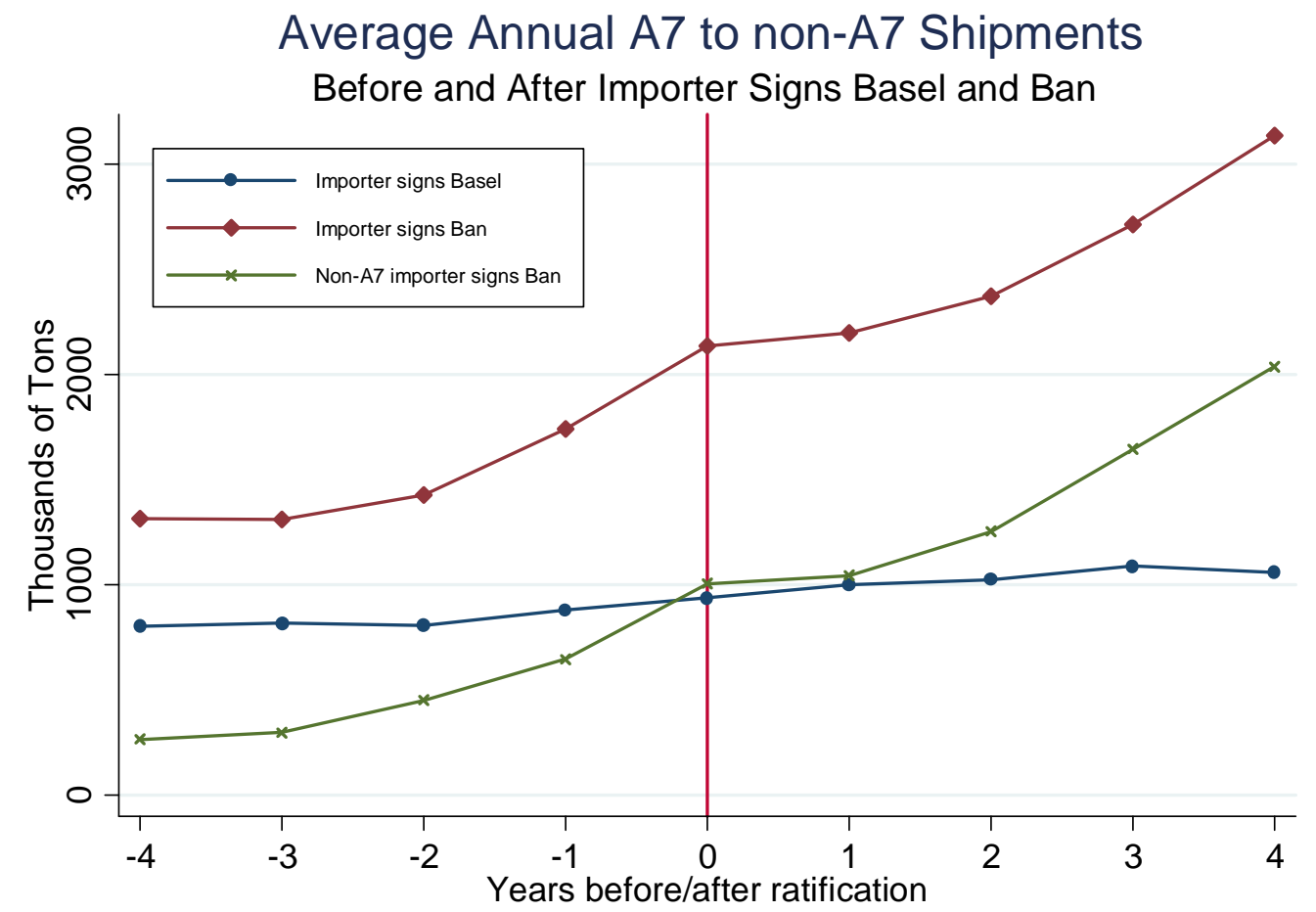


Figure 6: Rerouted Waste

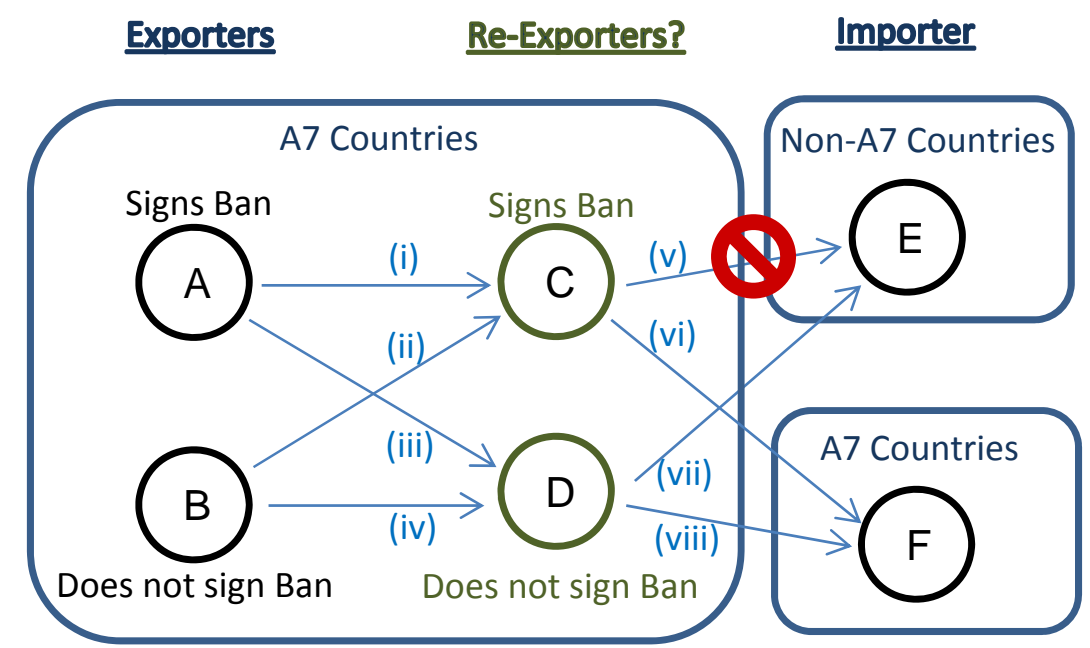

Figure 7

Share of Waste Shipped from Annex VIII to Ban Non-Ratifiers

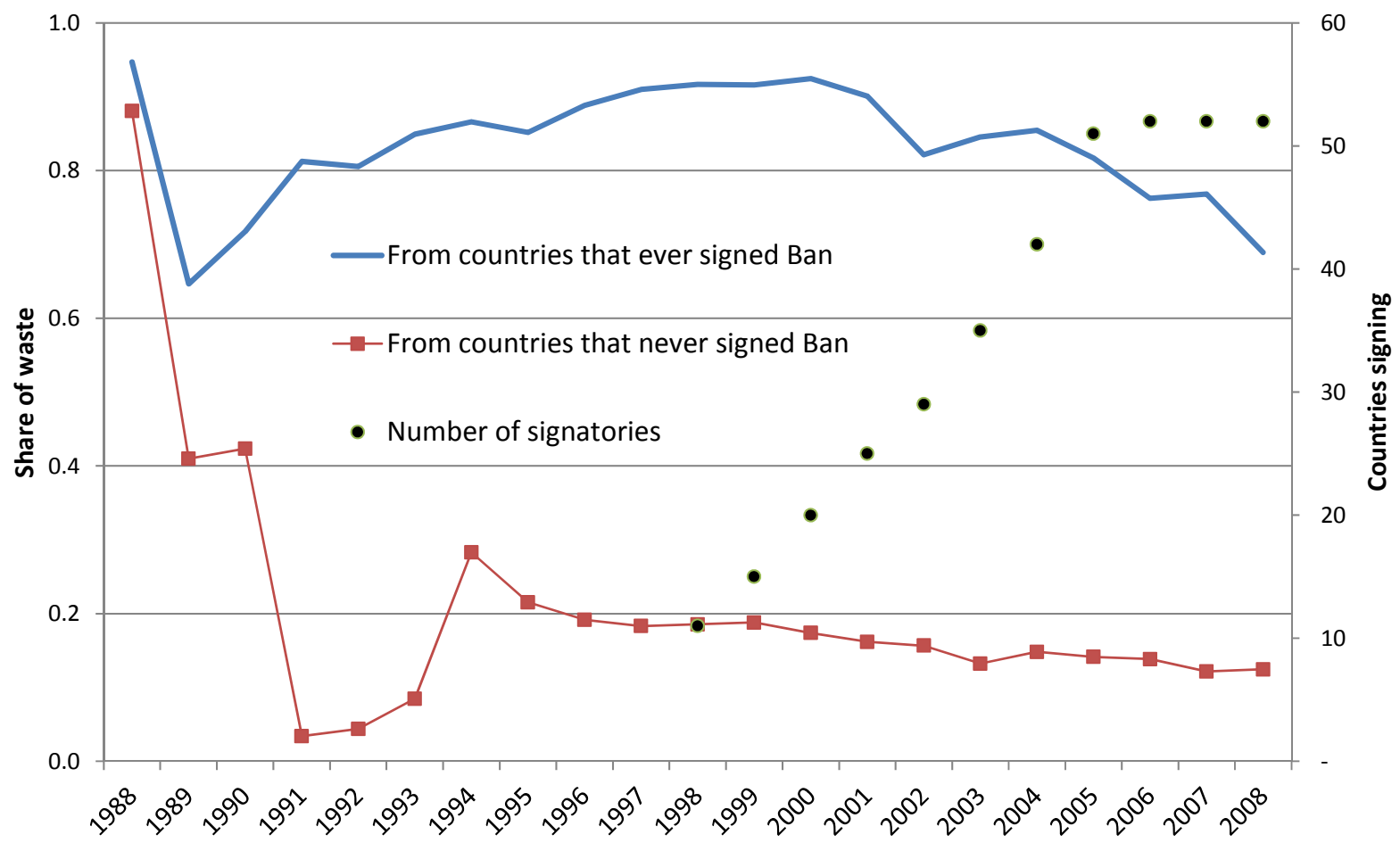




\section{Figure 8}

Rerouted Waste to non-A7 Countries via Ban non-Signers
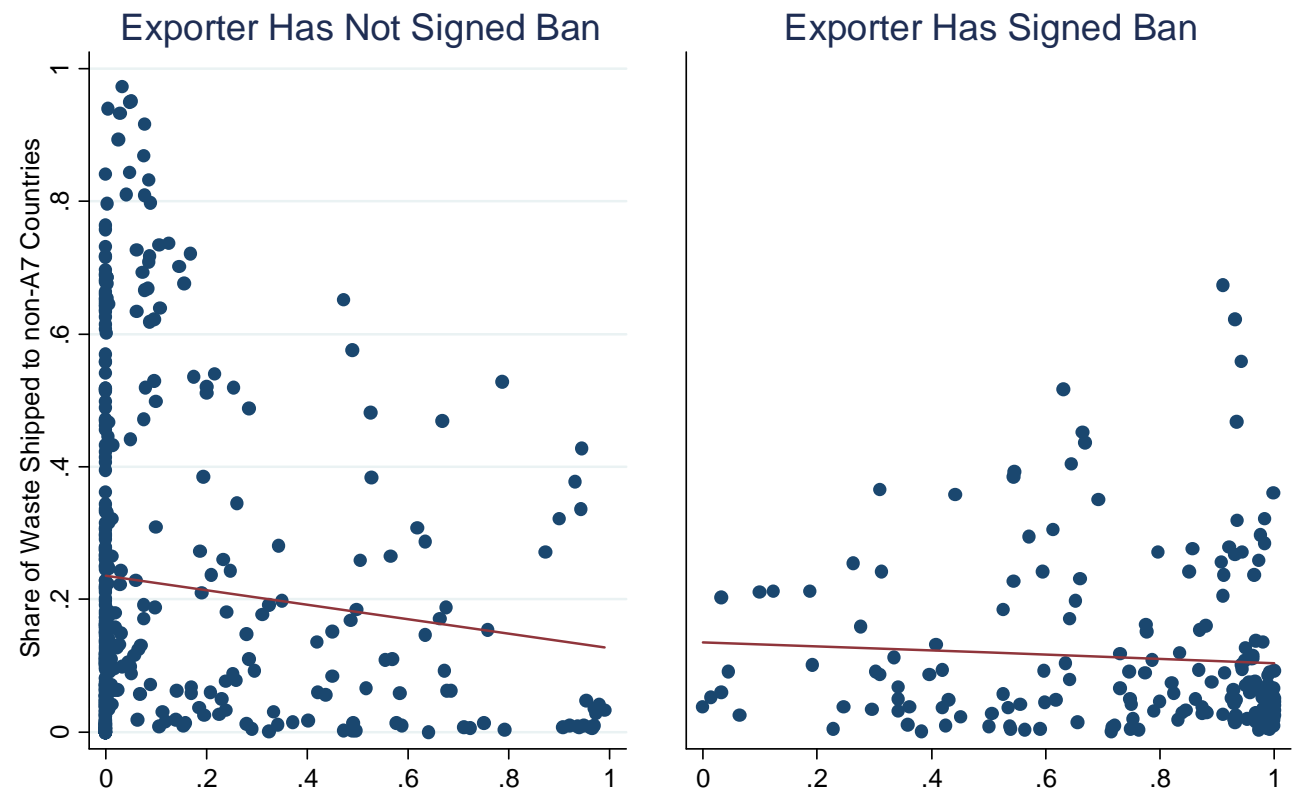

Share of Imports from Non-Signing A7 Exporters 
Appendix Table A1: HS 6 Code Classifications and Waste Commodity Descriptions

\begin{tabular}{|c|c|c|c|}
\hline HS6 Code & Commodity Description & HS6 Code & Commodity Description \\
\hline 230800 & $\begin{array}{l}\text { Vegetable mats./waste/residues/by-prods., } \\
\text { whether or not in pellets }\end{array}$ & 520210 & Cotton yarn waste (including thread waste) \\
\hline 262011 & Ash or residues containing hard zinc spelter & 700100 & Glass cullet, waste or scrap, glass in the mass \\
\hline 262019 & $\begin{array}{l}\text { Ash \& residues, containing zinc other than hard } \\
\text { zinc spelter }\end{array}$ & 711210 & $\begin{array}{l}\text { Waste or scrap containing gold as sole } \\
\text { precious metal }\end{array}$ \\
\hline 262020 & Ash or residues containing mainly lead & 711220 & $\begin{array}{l}\text { Waste/scrap containing platinum as sole } \\
\text { precious metal }\end{array}$ \\
\hline 262030 & Ash or residues containing mainly copper & 711290 & $\begin{array}{l}\text { Waste/scrap, precious metals except pure } \\
\text { gold/platinum }\end{array}$ \\
\hline 262040 & Ash or residues containing mainly aluminium & 720410 & Waste \& scrap of cast iron \\
\hline 262050 & Ash or residues containing mainly vanadium & 720421 & Waste or scrap, of stainless steel \\
\hline 262100 & Slag and ash nes, including seaweed ash (kelp) & 720429 & $\begin{array}{l}\text { Waste \& scrap of alloy steel other than } \\
\text { stainless steel }\end{array}$ \\
\hline 262110 & $\begin{array}{l}\text { Ash \& residues from the incineration of } \\
\text { municipal waste }\end{array}$ & 720430 & Waste or scrap, of tinned iron or steel \\
\hline 262190 & $\begin{array}{l}\text { Slag \& ash, other than from the incineration of } \\
\text { municipal waste }\end{array}$ & 720441 & $\begin{array}{l}\text { Waste from the mechanical working of iron or } \\
\text { steel nes }\end{array}$ \\
\hline 382510 & Municipal waste & 720449 & Ferrous waste or scrap, nes \\
\hline 382520 & Sewage sludge & 740400 & Copper/copper alloy waste or scrap \\
\hline 382530 & Clinical waste & 750300 & Nickel waste or scrap \\
\hline 382541 & Halogenated waste organic solvents & 760200 & Aluminium waste \& scrap \\
\hline 382549 & $\begin{array}{l}\text { Waste organic solvents other than halogenated } \\
\text { waste organic solvents }\end{array}$ & 780200 & Lead waste \& scrap \\
\hline 382550 & $\begin{array}{l}\text { Wastes of metal pickling liquors, hydraulic } \\
\text { fluids, brake fluids \& anti-freeze fluids }\end{array}$ & 790200 & Zinc waste \& scrap \\
\hline 382561 & $\begin{array}{l}\text { Wastes from chemical/allied industries, mainly } \\
\text { containing organic constituents, n.e.s. }\end{array}$ & 800200 & Tin waste \& scrap \\
\hline 382569 & Wastes from chemical/allied industries, n.e.s. & 810197 & Tungsten (wolfram) waste \& scrap \\
\hline 382590 & $\begin{array}{l}\text { Residual products of the chemical/allied } \\
\text { industries, n.e.s. }\end{array}$ & 810297 & Molybdenum waste \& scrap \\
\hline 391510 & Polyethylene waste or scrap & 810330 & Tantalum waste \& scrap \\
\hline 391520 & Polystyrene waste or scrap & 810420 & Magnesium waste \& scrap \\
\hline 391530 & Polyvinyl chloride waste or scrap & 810530 & Cobalt waste \& scrap \\
\hline 391590 & Plastics waste or scrap nes & 810730 & Cadmium waste \& scrap \\
\hline 400400 & $\begin{array}{l}\text { Rubber waste, parings and scrap (except hard } \\
\text { rubber) }\end{array}$ & 810830 & Titanium waste \& scrap \\
\hline 440130 & Sawdust, wood waste or scrap & 810930 & Zirconium waste \& scrap \\
\hline 470620 & $\begin{array}{l}\text { Pulps of fibres derived from recovered (waste \& } \\
\text { scrap) paper/paperboard }\end{array}$ & 811020 & Antimony waste \& scrap \\
\hline 470710 & $\begin{array}{l}\text { Waste or scrap of unbleached kraft or } \\
\text { paperboard }\end{array}$ & 811213 & Beryllium waste \& scrap \\
\hline 470720 & $\begin{array}{l}\text { Waste, scrap of paper, board of bleached } \\
\text { chemical pulp }\end{array}$ & 811222 & Chromium waste \& scrap \\
\hline 470730 & $\begin{array}{l}\text { Waste or scrap of paper or board of } \\
\text { mechanical pulp }\end{array}$ & 811252 & Thallium waste \& scrap \\
\hline 470790 & $\begin{array}{l}\text { Waste, scrap of paper, board, nes (including } \\
\text { unsorted) }\end{array}$ & 854810 & $\begin{array}{l}\text { Waste \& scrap of primary cells, primary } \\
\text { batteries \& electric accumulators }\end{array}$ \\
\hline
\end{tabular}




\begin{tabular}{|c|c|c|c|c|c|}
\hline HS6 Code & Commodity Description & Basel Code & HS6 Code & Commodity Description & Basel Code \\
\hline 262011 & $\begin{array}{l}\text { Ash or residues containing hard } \\
\text { zinc spelter }\end{array}$ & $\mathrm{A} 1070, \mathrm{~A} 1080$ & 382550 & $\begin{array}{l}\text { Wastes of metal pickling liquors, } \\
\text { hydraulic fluids, brake fluids \& anti- } \\
\text { freeze fluids }\end{array}$ & A1060 \\
\hline 262019 & $\begin{array}{l}\text { Ash or residues, containing zinc } \\
\text { other than hard zinc spelter }\end{array}$ & $\mathrm{A} 1070, \mathrm{~A} 1080$ & 382561 & $\begin{array}{l}\text { Wastes from chemical/allied } \\
\text { industries, mainly containing } \\
\text { organic constituents, n.e.s. }\end{array}$ & A3130, A3140 \\
\hline 262030 & $\begin{array}{l}\text { Ash or residues containing mainly } \\
\text { copper }\end{array}$ & A1090 & 382569 & $\begin{array}{l}\text { Wastes from chemical/allied } \\
\text { industries, n.e.s. }\end{array}$ & A4140, A4150 \\
\hline 262020 & $\begin{array}{l}\text { Ash or residues containing mainly } \\
\text { lead }\end{array}$ & A1080 & 382590 & $\begin{array}{l}\text { Residual products of the } \\
\text { chemical/allied industries, n.e.s. }\end{array}$ & A4140, A4150 \\
\hline 262110 & $\begin{array}{l}\text { Ash \& residues from the } \\
\text { incineration of municipal waste }\end{array}$ & $Y 47^{*}$ & 810730 & Cadmium waste \& scrap & A1010 \\
\hline 382510 & Municipal waste & Y46* & 811020 & Antimony waste \& scrap & A1010 \\
\hline 382520 & Sewage sludge & $Y 3, Y 23, Y 41^{* *}$ & 811213 & Beryllium waste \& scrap & A1010 \\
\hline 382530 & Clinical waste & A4020 & 780200 & Lead waste \& scrap & A1010 \\
\hline 382541 & $\begin{array}{l}\text { Halogenated waste organic } \\
\text { solvents }\end{array}$ & A3150 & 811252 & Thallium waste \& scrap & A1010 \\
\hline 382549 & $\begin{array}{l}\text { Waste organic solvents other than } \\
\text { halogenated waste organic } \\
\text { solvents }\end{array}$ & A3130, A3140 & 854810 & $\begin{array}{l}\text { Waste \& scrap of primary cells, } \\
\text { primary batteries \& electric } \\
\text { accumulators }\end{array}$ & $\begin{array}{c}\text { A1160, } \\
\text { A1170, A1180 }\end{array}$ \\
\hline
\end{tabular}

\footnotetext{
* Municipal waste and its residues from incineration are not listed specifically in Annex VIII of the Basel Convention. However, Annex II of the Convention does list Basel Codes Y46 and Y47 as household waste and its incineration as requiring special consideration as hazardous waste.

** Sewage sludge is also not listed specifically in Annex VIII of the Basel Convention. However, Annex I of the Convention does list categories of hazardous waste streams to be controlled that include waste from pharmacueticals (Y3), zinc waste (Y23), and halogenated organic solvents (Y41) among many others that have been demonstrated (Stokstad [2009]) to be present in biosolids from sewage sludge.
} 